\title{
Workers' Remittances to Developing Countries: A Survey with Central Banks on Selected Public Policy Issues
}

\author{
José de Luna Martínez
}

\begin{abstract}
This paper presents the findings of a survey of central banks in 40 developing countries across different regions in the world. The survey focused on the following four topics: (i) coverage of national statistics on remittances, (ii) cost of transferring and delivering remittances, (iii) regulatory regime for remittance transactions, and (iv) efforts of developing countries to channel remittance flows through formal financial institutions. The study found that in most countries existing data do not reflect the full amount of remittance inflows that they receive every year. Coverage of instruments and financial institutions through which remittances take place is limited. Moreover, only a few countries measure remittances that take place through informal channels. It was also found that the scope of financial authorities in developing countries to reduce remittance fees is limited, because a large part of the fees charged to customers are set by financial institutions located in the countries where transactions originate. Cooperation between sending and recipient countries is needed to reduce remittance costs. The survey found that in several countries money transfer companies are not properly supervised. Given the increasing international concerns on money laundering and terrorism financing issues, it is important that basic registration and reporting requirements are introduced for this type of company. Registration and reporting requirements should be designed in a way that they do not deter the further development of this type of financial institution. Finally, the survey found that most countries need to establish better mechanisms that would allow them to maximize the developmental effect of remittance inflows. By establishing new savings and investment instruments for remittance recipient households, a larger part of remittance flows might be channeled to finance productive investments, thus fostering economic growth.
\end{abstract}

World Bank Policy Research Working Paper 3638, June 2005

The Policy Research Working Paper Series disseminates the findings of work in progress to encourage the exchange of ideas about development issues. An objective of the series is to get the findings out quickly, even if the presentations are less than fully polished. The papers carry the names of the authors and should be cited accordingly. The findings, interpretations, and conclusions expressed in this paper are entirely those of the authors. They do not necessarily represent the view of the World Bank, its Executive Directors, or the countries they represent. Policy Research Working Papers are available online at http://econ.worldbank.org.

\footnotetext{
* José de Luna Martínez is a Senior Financial Economist at the World Bank. Comments on this paper are welcome. They can be sent to the author’s email address: Jdelunamartinez@worldbank.org
} 


\section{Table of Contents}

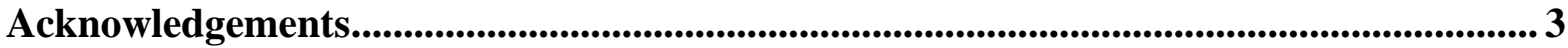

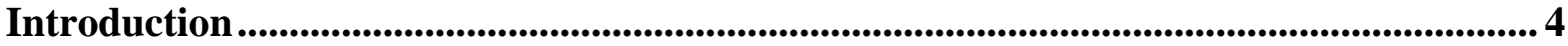

Section 1: Sources and Coverage of Remittance Statistics in Developing Countries ....... 6

What Types of Transactions are Reported as Remittances? ............................................ 9

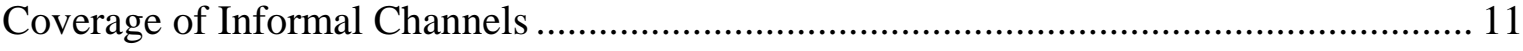

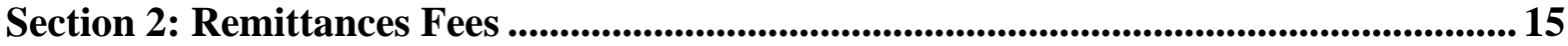

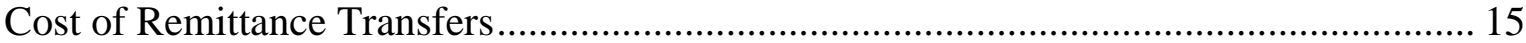

Improving Information Available to Consumers ......................................................... 18

Accounts in US Dollars or other International Currency.............................................. 19

Access to Central Banks’ Clearing and Settlement Systems .......................................... 20

Section 3: Regulatory Issues.............................................................................................. 22

Oversight of Institutions Delivering Remittances..................................................... 22

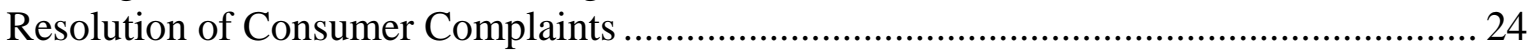

Taxation of Remittances .............................................................................. 24

Section 4: Recent Initiatives in Developing Countries to Facilitate Remittances Flows through Formal Channels ............................................................................................................. 26

Bilateral Dialogue and Cooperation Between Authorities................................................ 26

Incentives for the Use of Formal Remittance Channels............................................. 27

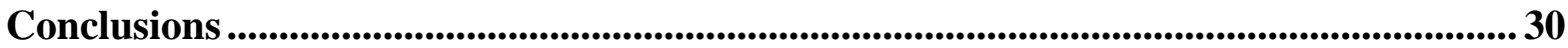

Annex 1. World Bank Survey on Remittances- Questions for Central Banks ................. 36

Annex 2 - Country Data .................................................................................... 42

Annex 3. Recent Country Initiatives to Improve Statistical Data on Remittances ............ 43 


\section{Acknowledgements}

The author is grateful to all the officials in the 40 central banks that kindly accepted to participate in this survey, share their valuable knowledge, and clarify a number of countryspecific issues. Ole E. Andreassen, Raúl Hernández-Coss, Robert Keppler, María Soledad Martínez Peria, Latifah Merican, and Dilip Ratha read preliminary drafts of the paper and provided valuable comments and suggestions. Neil Patterson and Jens Reincke from the IMF's Statistics Department also reviewed the paper and made valuable observations. The paper benefited from comments by the participants at the "International Meeting on Measuring Remittances” held in Washington, DC, on January 24-25, 2005. The author would like to thank Patricia Barbery and Corrado Barberis for providing excellent research assistance. 


\section{Introduction}

The flow of workers' remittances to developing countries has increased dramatically in recent years. While in 1996 developing countries received \$58 billion dollars in remittances, in 2003 remittance inflows amounted to $\$ 96$ billion dollars (see Annex 2 for detailed data on remittances). It is expected that the volume of workers' remittances will surpass $\$ 110$ billion dollars in 2004. Workers' remittances constitute an increasingly important source of income for many families, especially poor families, whose relatives have emigrated to other countries in search of better employment opportunities. Moreover, after foreign direct investment, workers' remittances constitute the largest source of external financing for developing countries. For 25 developing countries, remittance flows represented more than 5\% of their respective GDP in 2003.

In an effort to improve the developmental impact of remittances in recipient countries, the World Bank is currently conducting a series of studies to better understand the characteristics of remittances, as well as the financial infrastructure underpinning money transfers in both sending and recipient countries. In particular, the World Bank is talking to central banks, money transfer companies, and senders and recipients of remittances in a number of developing and developed economies.

The purpose of this paper is to present the findings of a survey conducted by the World Bank with central banks in 40 developing countries (other World Bank surveys with market participants in the remittance industry and senders and recipients in selected countries are currently under preparation). This survey focused on the following four topics: (i) coverage of national statistics on remittances, (ii) cost of transferring and delivering remittances, (iii) regulatory regime for remittance transactions, and (iv) recent initiatives in developing countries to channel remittance flows through formal financial institutions. ${ }^{1}$

Most of the information contained in this paper was kindly provided to the World Bank by the central banks of participating countries between July and December 2004. The list of 40 developing countries in Asia, Europe and Central Asia, Latin America and the Middle East and Africa that have participated in this survey is presented in Table 1. Although more countries may participate in this survey in the future, the author believes that the preliminary findings of this survey are sufficiently robust to be presented to the general public to generate discussions and stimulate the debate about the survey's main findings.

\footnotetext{
${ }^{1}$ In this paper, the term "remittances" refers to the money that migrant workers send to their relatives in their countries of origin. Remittances in kind are not analyzed in this paper.
} 
Table 1. Developing Countries that Participated in the Survey*

\begin{tabular}{|c|c|c|c|}
\hline Asia & $\begin{array}{c}\text { Europe and Central } \\
\text { Asia }\end{array}$ & Latin America & $\begin{array}{c}\text { Middle East and } \\
\text { Africa }\end{array}$ \\
\hline $\begin{array}{ll}\text { 1. } & \text { Bangladesh } \\
\text { 2. } & \text { India } \\
\text { 3. } & \text { Indonesia } \\
\text { 4. } & \text { Pakistan } \\
\text { 5. } & \text { Philippines } \\
\text { 6. } & \text { Sri Lanka } \\
\text { 7. } & \text { Thailand }\end{array}$ & $\begin{array}{ll}\text { 8. } & \text { Azerbaijan } \\
9 . & \text { Belarus } \\
\text { 10. } & \text { Bulgaria } \\
\text { 11. } & \text { Croatia } \\
\text { 12. } & \text { Cyprus } \\
\text { 13. } & \text { Czech Rep. } \\
\text { 14. } & \text { Georgia } \\
\text { 15. } & \text { Latvia } \\
\text { 16. } & \text { Moldova } \\
\text { 17. } & \text { Poland } \\
\text { 18. } & \text { Russian Fed. } \\
\text { 19. } & \text { Serbia } \\
\text { 20. } & \text { Slovenia } \\
\text { 21. } & \text { Turkey }\end{array}$ & $\begin{array}{ll}\text { 22. } & \text { Bolivia } \\
\text { 23. } & \text { Brazil } \\
\text { 24. } & \text { Colombia } \\
\text { 25. } & \text { Costa Rica } \\
\text { 26. } & \text { Ecuador } \\
\text { 27. } & \text { El Salvador } \\
\text { 28. } & \text { Guatemala } \\
\text { 29. } & \text { Guyana } \\
\text { 30. } & \text { Haiti } \\
\text { 31. } & \text { Honduras } \\
\text { 32. } & \text { Mexico } \\
\text { 33. } & \text { Nicaragua } \\
\text { 34. } & \text { Peru } \\
\text { 35. } & \text { Uruguay } \\
\text { 36. } & \text { Venezuela }\end{array}$ & $\begin{array}{ll}\text { 37. } & \text { Egypt } \\
\text { 38. } & \text { Tanzania } \\
\text { 39. } & \text { Tunis } \\
\text { 40. } & \text { Uganda }\end{array}$ \\
\hline
\end{tabular}

*This group of 40 countries received $\$ 68.2$ billion dollars in remittance flows during 2003, which accounts for $73 \%$ of total remittance flows to developing countries.

The paper is divided in five sections. The first section assesses the data on remittance inflows in developing countries. It analyzes which types of financial and non-financial institutions report their remittance transactions to central banks or other financial sector authorities, what types of transactions are reported, and to what extent money transfers that occur through informal channels are captured in official statistics. The second section analyzes the cost of transferring remittances to developing countries and examines some proposals formulated in various international fora to reduce remittance fees. The third section focuses on regulation, analyzing country approaches used to monitor money transfer companies, resolution of consumer complaints and taxation of remittances. The fourth section reviews the efforts of financial authorities in developing countries to facilitate money through formal financial institutions and enhance the developmental impact of remittances. The final section draws some policy recommendations from the survey findings and highlights the areas where policy-makers may want to devote more attention in order to improve their information on remittances, facilitate money transfers between countries, lower transaction costs, and improve the overall regulatory regime for remittance transactions. 


\section{Section 1: Sources and Coverage of Remittance Statistics in Developing Countries}

In general terms, a remittance transfer can be divided in three phases, as illustrated in Figure 1. The first phase occurs in the country where the migrant works and the transaction originates. A remittance transaction is originated when a migrant goes to a bank, money transfer company, credit union, or any other originating point (such as grocery store, post office, gas station, etc.) to transfer funds to relatives or friends in his home country. The second phase takes place when funds are transferred from the originating country to another foreign country. Finally, the third phase occurs when funds arrive in the destination country and are paid to the beneficiary at a commercial bank, money transfer company or any other distribution point (such as ATMs, grocery store, post office, etc).

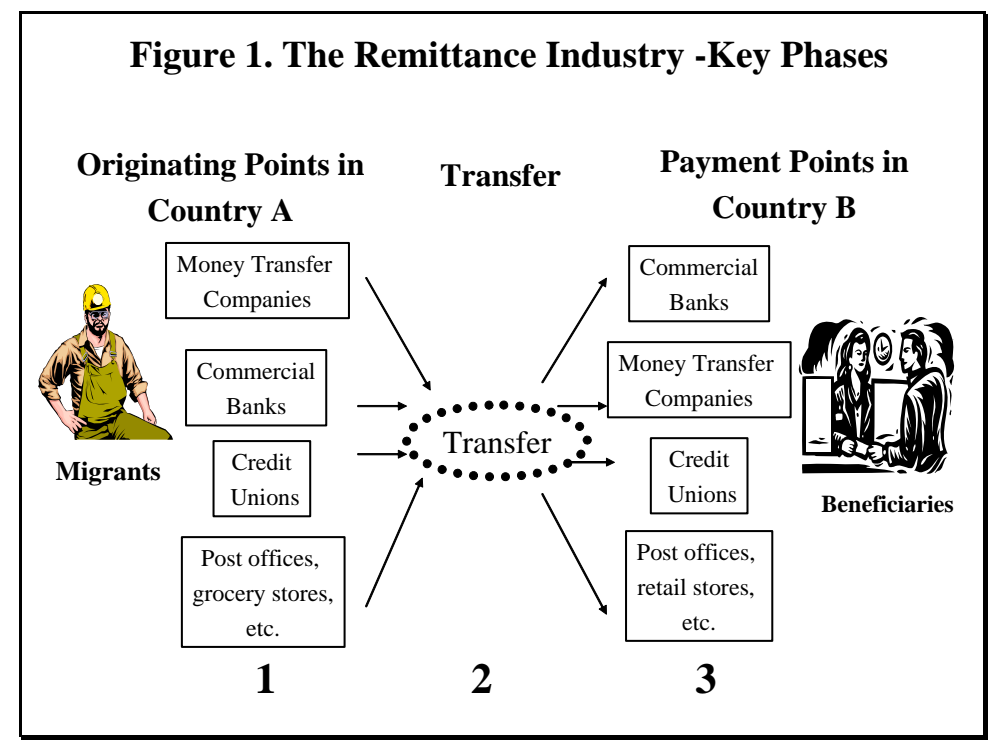

It is important to note that in most cases, banks, credit unions, post offices, exchange bureaus, and micro-finance institutions in developing countries act as "paying agents" of financial institutions and money transfer companies located in the countries where the transactions originate. Only a few banks or financial institutions in developing countries have branches or subsidiaries overseas that serve both senders and recipients of remittances.

The first issue this survey attempted to explore was to what extent the balance of payment statistics of developing countries reflect the volume of remittance flows that countries receive every year (third phase). ${ }^{2}$ As shown in Table 2 below, the survey found that in many countries the coverage of remittances in balance of payments statistics is partial, because remittances

\footnotetext{
${ }^{2}$ In the countries covered in this survey, remittance data for balance of payment statistics is collected by central banks. However, it is worth noting that in some other countries data is not collected by central banks but by national statistics agencies.
} 
paid directly by non-bank financial institutions - such as money transfer companies, exchange bureaus, credit unions, post offices, etc -- are frequently not covered in balance of payment statistics. ${ }^{3}$ As shown in Table 2, in all 40 countries covered in the survey commercial banks participate in the payment of remittances. $90 \%$ of countries collect remittance data from commercial banks. In 20 of 40 countries, exchange bureaus, credit unions, and other non-bank financial institutions pay remittances, but only $65 \%$ of those countries collect remittance data from those institutions. In 39 of 40 countries, money transfer companies pay remittances, but only 38\% of central banks collect data from them. Finally, in 26 of 40 countries post offices pay remittances, but only in $35 \%$ of those countries remittance data is collected from post offices. ${ }^{4}$

Table 2. Central Banks' Sources of Data on Remittance Inflows

\begin{tabular}{|c|c|c|c|c|}
\hline & $\begin{array}{l}\text { Commercial } \\
\text { Banks }\end{array}$ & $\begin{array}{c}\text { Exchange } \\
\text { bureaus and } \\
\text { other inst. }\end{array}$ & $\begin{array}{c}\text { Money } \\
\text { Transfer } \\
\text { Companies }\end{array}$ & $\begin{array}{l}\text { Post } \\
\text { Offices }\end{array}$ \\
\hline $\begin{array}{l}\text { a. Countries where remittances } \\
\text { are paid by: }\end{array}$ & 40 & 20 & 39 & 26 \\
\hline $\begin{array}{l}\text { b. Central banks that collect data } \\
\text { on remittance payments made } \\
\text { by: }\end{array}$ & 36 & 13 & 15 & 9 \\
\hline $\begin{array}{l}\text { c. Percent of central banks that } \\
\text { collect data from: (b / a) }\end{array}$ & $90 \%$ & $65 \%$ & $38 \%$ & $35 \%$ \\
\hline
\end{tabular}

Because not all countries collect data from all the financial and non-financial institutions that pay remittances, the official data in many countries do not reflect the full value of remittance inflows that they receive every year. What is the value of remittances not covered in official statistics is a difficult question to answer due to lack of data at both international and country levels. In fact, one of the questions central banks were asked was whether they knew the market share among all the different service providers paying remittances in their countries, even if they did not capture this information in their official statistics. As shown in chart 1, only $28 \%$ of central banks responded positively. Interestingly, all countries that responded

\footnotetext{
${ }^{3}$ There is no universally accepted definition of remittances. The fifth edition of the IMF's Balance of Payments Manual (BPM5) provides definitions for "compensation of employees”, "workers' remittances" and "migrants' transfers". All the above three categories are frequently considered "remittances" by analysts and data users. A detailed review of these three categories and some of their limitations can be found at (Neil Patterson and Jens Reincke, 2005).

${ }^{4}$ In some countries, a number of money transfer companies and non-bank financial institutions settle their remittance transactions through local commercial banks. In those cases, it is possible that remittance transactions conducted by these institutions are reported by commercial banks to the central bank. Unfortunately, this study did not have the resources to investigate what percentage of non-bank financial institutions in developing countries settle their remittance transactions through local commercial banks. Moreover, it was not possible to examine the existing data reporting procedures in commercial banks - in some countries banks are only required to report individual remittance transactions above a certain threshold amount -- to verify that transactions are properly recorded as remittances. Without doubt, all these topics require further research.
} 
positively are located in Latin America. This may reflect the valuable efforts that many countries in this region have undertaken in recent years to improve their remittance data.

\section{Chart 1. Payment of Remittances - Market Share Among Different Service Providers}

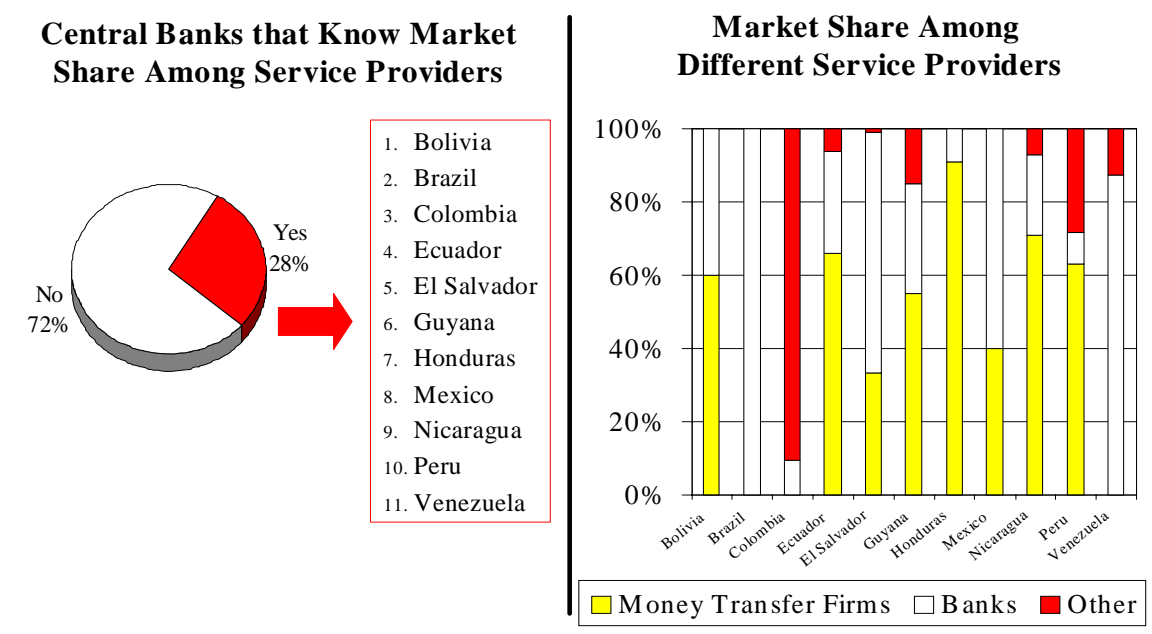

As shown in chart 1 , in six of the eleven developing countries that had this type of information available, money transfer companies dominate the market for delivery of remittances with more than a 50\% market share (Bolivia, Ecuador, Guyana, Honduras, Nicaragua and Peru). In two countries, Brazil and Venezuela, commercial banks account for $100 \%$ and $87 \%$ of the market for remittance payments, respectively, ${ }^{5}$ while in Colombia, exchange bureaus dominate $90 \%$ for the market of remittance payments. Because at this time no information is available on the market share among services providers in other developing countries, it is difficult to estimate the amount of remittances inflows that is not reflected in balance of payments statistics.

There are particular reasons that explain why many of the surveyed countries fail to cover in their statistics the remittance transactions conducted by money transfer companies. First, in those countries money transfer companies are neither regulated nor supervised by the central bank or any other financial sector authority, as explained in Section 3. In fact, in those countries, money transfer companies are not established as "financial institutions", but as commercial firms. As a result, they are not subject to regulatory or oversight requirements applicable to financial institutions. Although in some countries, due to recent anti-money laundering legislation, money transfer companies have been required to register themselves

\footnotetext{
${ }^{5}$ According to authorities in Brazil, money transfer companies can only pay remittances through commercial banks. In Venezuela, money transfer companies are allowed to pay remittances, but most of them do it through local commercial banks, which act as agents of these companies.
} 
with financial authorities and report any suspicious transactions, they do not report the value or the number of their remittance transactions.

Similarly, in many countries remittance transactions paid by post offices are not reported to the central bank or any other type of financial sector authority. In most cases, the financial operations of post offices are regulated and monitored by the Ministry of Communications and not a financial sector authority.

\section{What Types of Transactions are Reported as Remittances?}

Unlike the 1970s and 1980s, when migrants from developing countries working in industrialized economies had few options to send money to their home countries through financial institutions - and if available, money transfers were expensive, took several days to get processed, and could only be delivered to a few locations -- nowadays the number of channels and financial instruments available in the marketplace to transfer money overseas has increased dramatically. Moreover, the average customer fees of remittance transactions has declined, while the timeframe to complete transactions has been drastically reduced - in some cases to just a few minutes -- thanks to the use of modern technology.

Nowadays, migrant workers can send money to their relatives in their home countries using a wide range of institutions and instruments. In the USA, for instance, -- the largest source country for remittances sent to developing countries - many commercial banks and credit unions offer migrants the possibility to send money home through electronic transfers, drafts, money orders, dual debit cards and pre-paid cards. Also, money transmitters (e.g. Western Union, Vigo, MoneyGramm) in developed economies have established a large network of agents (agents are usually grocery stores, gas stations, pharmacies and other retail stores) that offer customers the possibility to transfer money worldwide in just a few minutes through electronic transactions operated through their own networks. Some money transmitters also allow customers to initiate a remittance transaction via the internet or by phone. Moreover, the US post offices also offer customers products to send money electronically to ten countries, as well as international postal money orders to all other countries.

Table 3. Channels and Instruments for Sending Remittances

\begin{tabular}{|c|c|}
\hline $\begin{array}{l}\text { Channels and Institutions Through Which } \\
\text { Remittance Transactions can be Initiated }\end{array}$ & Financial Instruments \\
\hline $\begin{array}{ll}\text { - } & \text { Phone } \\
\text { - } & \text { Internet } \\
\text { - } & \text { Commercial banks } \\
\text { - } & \text { Credit unions } \\
\text { - } & \text { Money transfer companies (MTCs) } \\
\text { - } & \text { MTC’s agents (gas stations, drug stores, } \\
\text { - } & \text { Petail stores, etc.) } \\
\text { Post offices }\end{array}$ & $\begin{array}{ll}\text { - } & \text { Telegraphic Wire Transfer } \\
\text { - } & \text { Electronic wire transfer through SWIFT. } \\
\text { - } & \text { EuroGiro } \\
\text { - } & \text { Drafts and International Money Orders } \\
\text { - } & \text { Traveller cheques } \\
\text { - } & \text { ATM Cards } \\
\text { - } & \text { Gift Cards } \\
\text { - } & \text { Debit Cards }\end{array}$ \\
\hline
\end{tabular}


Given the wide range of instruments to send money to developing countries, what types of transactions are recorded as remittances by central banks? According to this survey, in most countries (33 out of 40 countries, or $83 \%$ of countries) remittance transactions that occur via electronic wires transmitted by commercial banks are captured in official statistics. Remittances that occur via money orders and drafts - regardless of which type of financial or non-financial institution pays the beneficiary -- are documented as remittances in $63 \%$ and $45 \%$ of countries in this survey, respectively. Not surprisingly, remittances that are collected by beneficiaries through cash withdrawals at ATMs (using dual cards) are hardly reported, only $23 \%$ of central banks cover them in their remittances statistics.

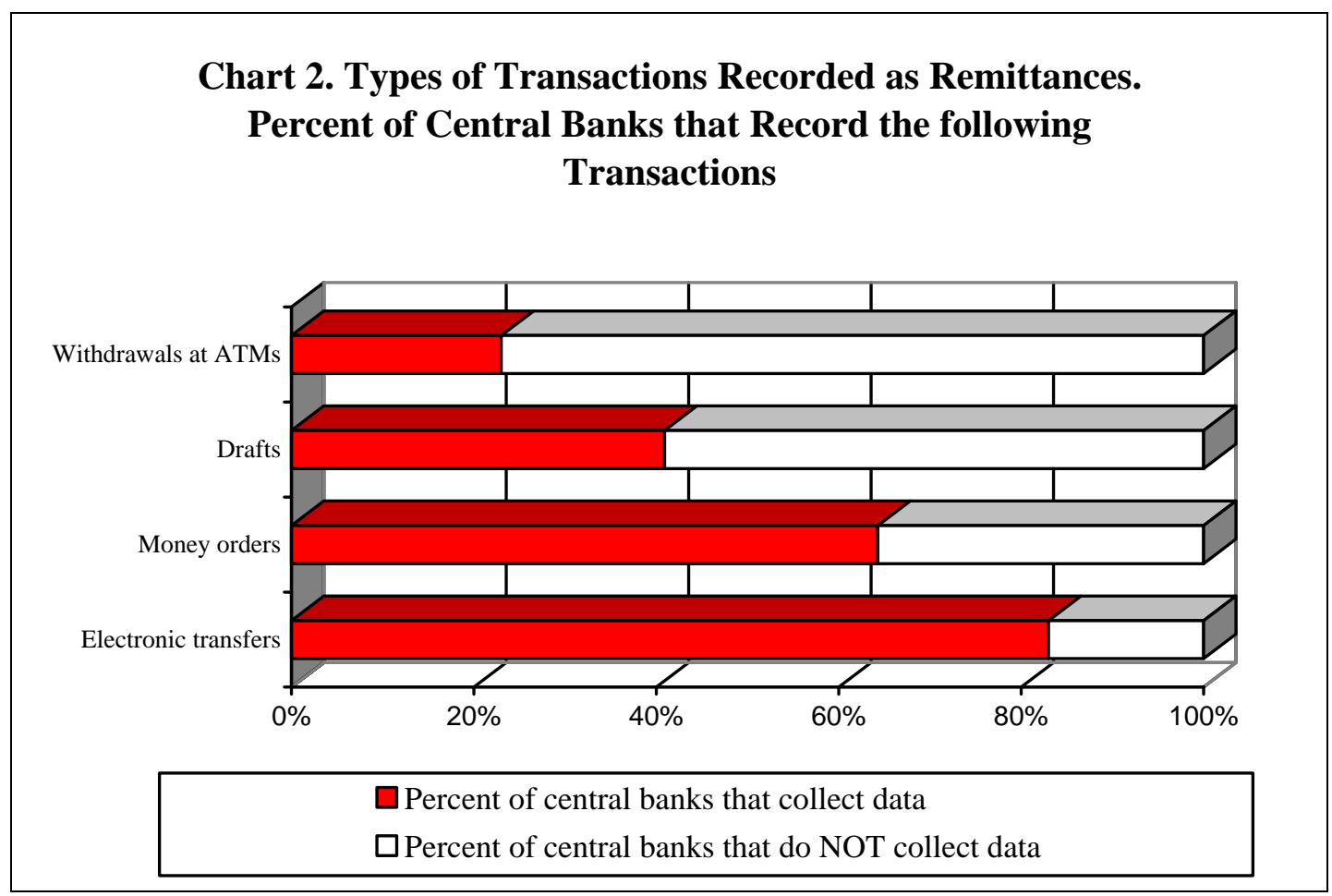

With the increasing number of money transfer products available in the marketplace, it is becoming more difficult for central banks to cover remittance transactions, especially when the transactions occur through new products, such as dual debit cards or smart cards. Moreover, it is also becoming more difficult to distinguish which transactions are actually remittances from those that are not. For instance, a cash withdrawal at an ATM using a card issued by a bank in a foreign jurisdiction may not necessarily be a remittance transaction. It may just be a cash withdrawal by a foreign tourist.

It has also become difficult for central banks to identify the source country of remittances, as well as the number of transactions that occur through the different financial instruments used by migrants to send remittances. According to the survey, only $50 \%$ of central banks have information on the number of remittance transactions (drafts, electronics wires, etc) that they cover in their statistics. For other countries, remittance data is available only on an aggregated basis. 


\section{Coverage of Informal Channels}

Despite the increasing number of financial products available in the marketplace to transfer money between countries, some migrants may choose for several reasons to send money to their home country through informal channels, such as:

- Sending cash with people traveling to their home country.

- Putting the money in an envelope and mailing it.

- Using the services of Hawala-type of money transfers. ${ }^{6}$

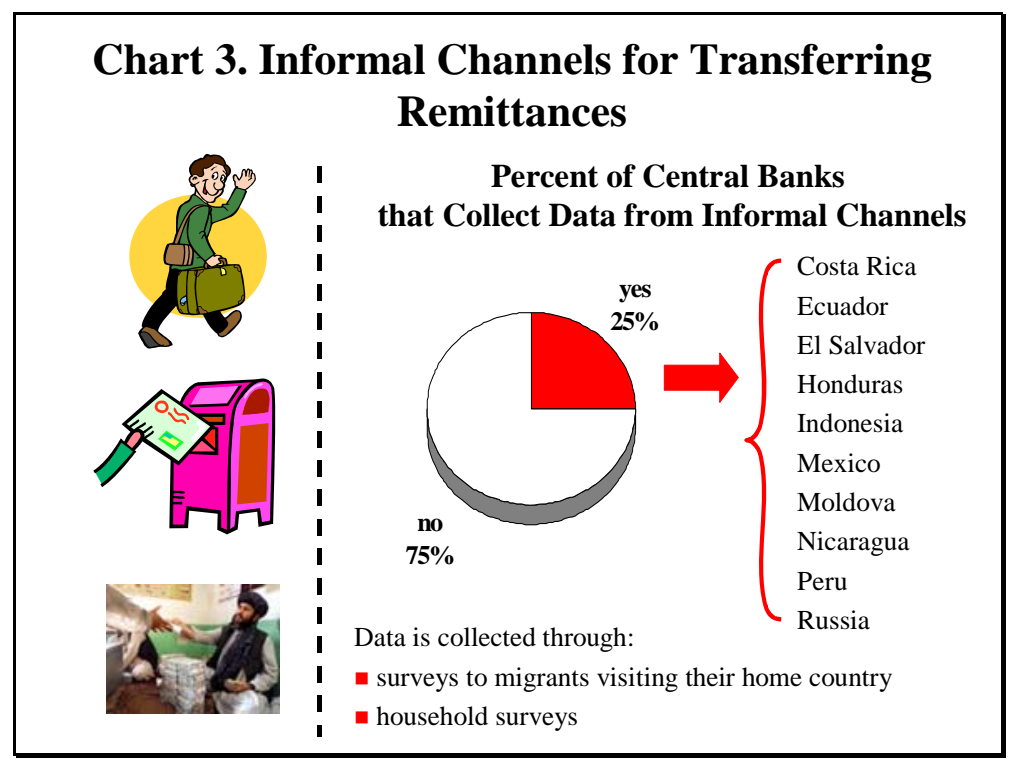

As shown in chart 3, of the 40 countries covered in the survey 10 central banks have developed tools to measure the volume of remittances inflows that occur through informal channels. In these countries, information is normally collected through surveys of migrants visiting their home country and/or household surveys. Countries like Ecuador and Honduras conduct surveys to migrants at the country's main points of entry (usually airports) every year, especially during holiday seasons when the inflow of migrant visitors reaches its peak (e.g. Christmas and New Year, Easter, Chinese New Year, etc.) ${ }^{7}$ Other countries such as El Salvador conduct household surveys every year to estimate the total value that they receive in remittances either through formal or informal channels.

\footnotetext{
${ }^{6}$ Empirical studies indicate that the choice of mechanism used is not just related to transaction fees, but also to the speed of service and the availability of financial services to both the sender and the beneficiary. See Manuel Orozco (2004b).

${ }^{7}$ The survey did not assess the scope, methodology and adequacy of the surveys conducted by this group of countries. This is an issue that deserves much more attention in the future.
} 
It is beyond the scope of this study to discuss the effectiveness and adequacy of countries' surveys to measure remittance flows. This is a topic that needs to be analyzed separately. However, it is important to note that because most countries do not measure remittances that occur through informal channels, it is not possible to estimate the total value of remittances that developing countries receive every year through those means. Moreover, because in most countries not even an estimate of this type of flow is incorporated in balance of payments statistics, the value of workers' remittances is probably under-reported.

Although some efforts are currently underway in some of the countries covered in the survey to improve remittance statistics (see Annex 3), much more effort is required. National statistics on remittances are expected to provide comprehensive data on the value and composition of remittances that countries receive every year, covering all different types of instruments and channels through which migrants send money to their home countries. Moreover, statistics on remittances are important for the formulation of macroeconomic policy, especially for countries with a large part of their population living abroad, because large remittance inflows can affect the level of savings, investment and consumption. Remittance data also constitutes a basic instrument for government and non-government agencies that seek to improve the living conditions of senders and beneficiaries of incoming remittances. Furthermore, data on remittances constitutes an important tool to monitor crossborder flows of money and timely detect money-laundering or other illicit activities that may undermine the integrity of a financial system.

Recently, thanks to major improvements in the way remittance data is collected, some developing countries (e.g. Mexico) are starting to realize that the value of remittances they receive every year is actually much more than they had previously thought (see Box 1 below). Moreover, better remittance data is encouraging authorities in developing countries to develop new policies to maximize the developmental impact of those flows by increasing the availability of savings and investment instruments for senders and recipients of remittances. For instance, in some countries in Latin America poor families can use their regular remittance income as the basis to acquire life and non-life insurance products, and become eligible for housing financing and consumer credit, which may help them improve their living conditions. Also, recent studies suggest that better remittance data has encouraged an increasing number of private financial institutions -especially international banks -- to enter into the remittance market or offer new financial products to serve the needs of senders and recipients of remittances (see Raul Hernandez-Coss, 2004).

At an international level more guidance is needed to improve the existing tools to collect data on remittances. In particular, there is a need to establish homogeneous reporting requirements across countries that do not undermine the competitive position of market players, especially small institutions. In addition, there is a need to develop better tools to measure remittance transactions that occur through increasingly sophisticated financial instruments, such as dual debit cards, store-value cards and other card-based transactions, as well as remittances that occur through informal channels. 


\section{Box 1. Improving Remittance Data in Mexico}

Mexico's official data indicates that remittance inflows increased from US \$8.8 billion in 2000 to US $\$ 17.2$ billion in 2004, an increase of 95\%. According to Mexico’s central bank, this increase in remittance inflows reflects major improvements in the way remittances are reported by financial institutions to Mexico's central bank, rather than a major increase in the number of Mexican migrants working in the USA, which increased during the same period by $22 \%$.

Chart 4. Remittance Inflows to Mexico from the USA

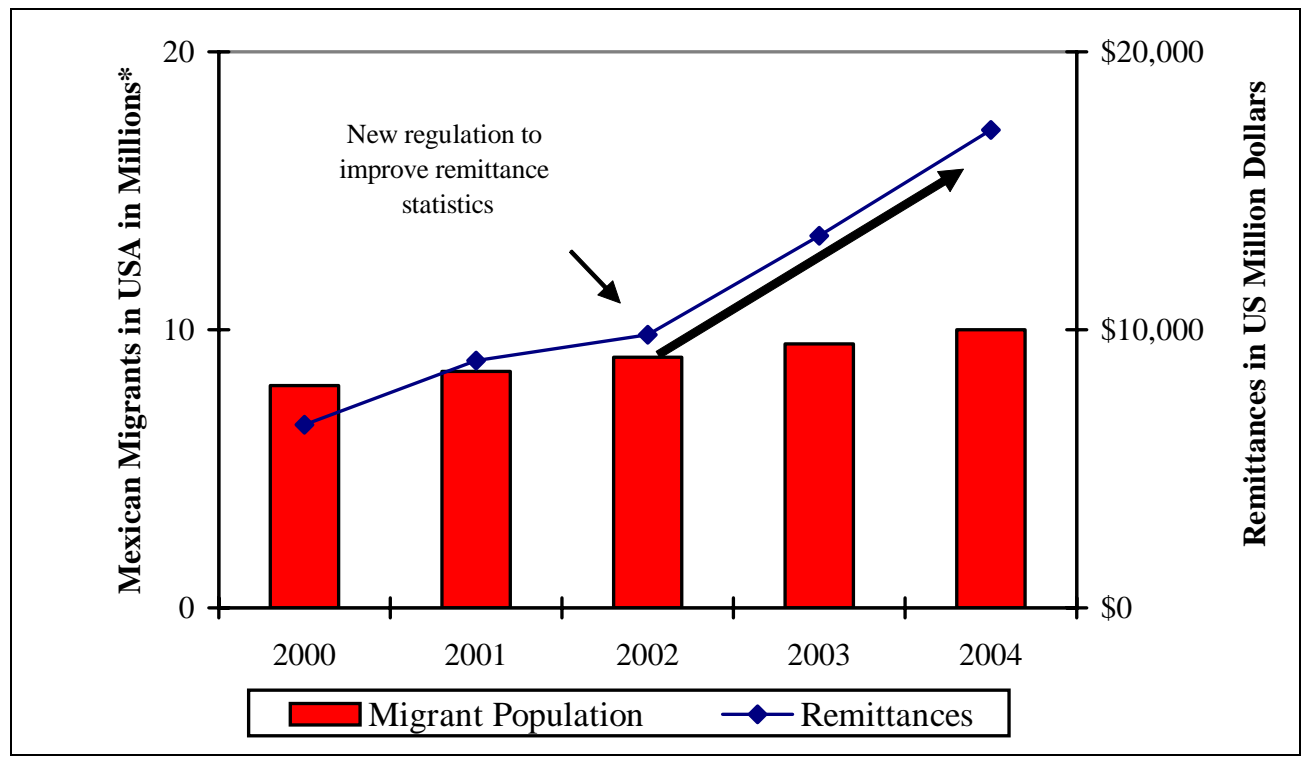

*It refers to migrants born in Mexico and currently living in the USA.

Sources: CONAPO and Central Bank of Mexico.

Before 2002, only commercial banks reported their remittance transactions to Mexico's central bank. On October 28, 2002, Mexico’s central bank issued a new regulation requiring all money transfer companies to register at the central bank and report the value of their remittance transactions on a monthly basis. As shown in Chart 4, after the new reporting system was introduced, remittance statistics started to see a rapid growth. While other factors may also have influenced the increase in remittance inflows, the improvement in data collection practices has largely contributed to it.

Moreover, at the international level it is also important to address some misclassification problems that may cause either sub- or over-reporting of remittance inflows. For example, are funds borrowed by a migrant in his host country and invested in his home country (e.g. purchase real estate) a remittance? Are guidelines followed by banks sufficiently clear to prevent certain trade-related transactions from being reported as remittances? Clearly, these are issues that need to be addressed at an international level so that remittance data is consistent across countries. 
The IMF is currently revising its Balance of Payments Manual. The new Manual is expected to help countries address their problems in measuring workers' remittances. Moreover, at the time this paper is being written, an international group led by the IMF, World Bank and United Nations is reviewing the existing definitions of workers' remittances across countries and preparing specific recommendations to improve mechanisms to collect remittance data. ${ }^{8}$

8 More information on the work of this International Task Force is available at: www.worldbank.org/data/remittances.htm. 


\section{Section 2: Remittances Fees}

A second topic covered in this survey refers to the fees that migrants and beneficiaries pay to financial and non-financial institutions to send and receive remittances. Although fees have declined in the past years due to increasing competition and the emergence of new financial products that allow electronic money transfers at low cost, they still remain high for many corridors. In particular, the survey examined what is the scope for central banks in developing countries to reduce remittance fees. It also examined some of the proposals formulated in international fora to help developing countries reduce remittances fees.

\section{Cost of Remittance Transfers}

In general terms, the fees associated with transferring remittances from one country to another have three components, as illustrated in figure 2:

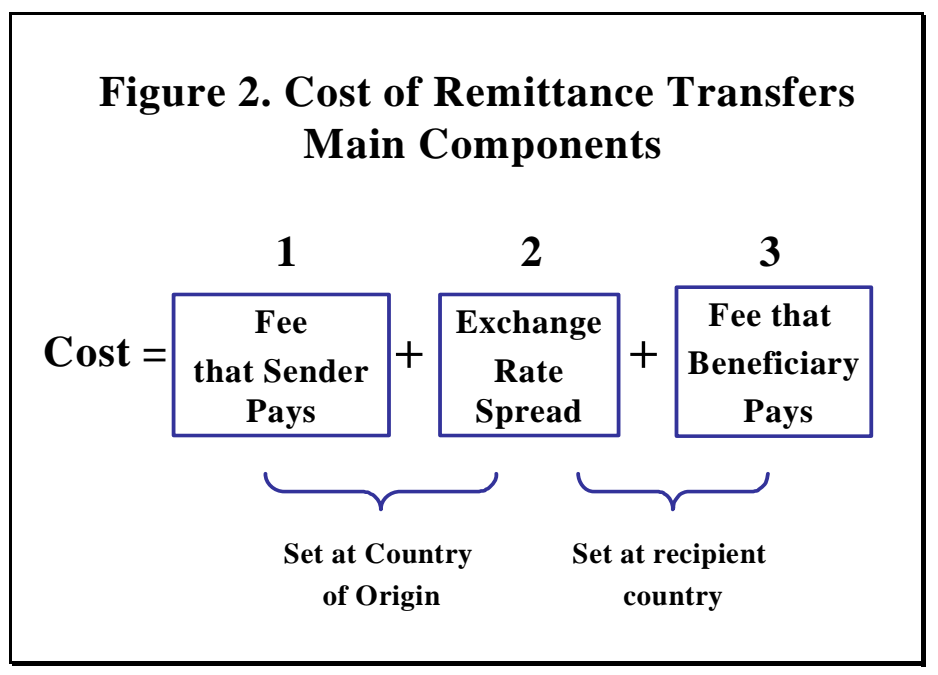

- The first component is the fee that the sender pays to the service provider in the originating country for transferring money to another country.

- The second component refers to the exchange rate spread (use of a higher exchange rate than the one prevailing in the market) that companies apply to convert a remittance into the local currency in which the beneficiary receives his money. There are, however, some cases in which the remittances can be sent and paid in the same currency (e.g. remittances sent from the USA to some developing countries, such as Ecuador and El Salvador); in those cases, this cost component does not apply.

- The third component is the fee that the beneficiary sometimes needs to pay when he receives his money. This type of fee varies according to the institution and the instrument used to receive remittances; sometimes banks charge a fee for depositing remittances into the beneficiary's account, for the use of an ATM to withdraw funds, or for the payment of money orders. 


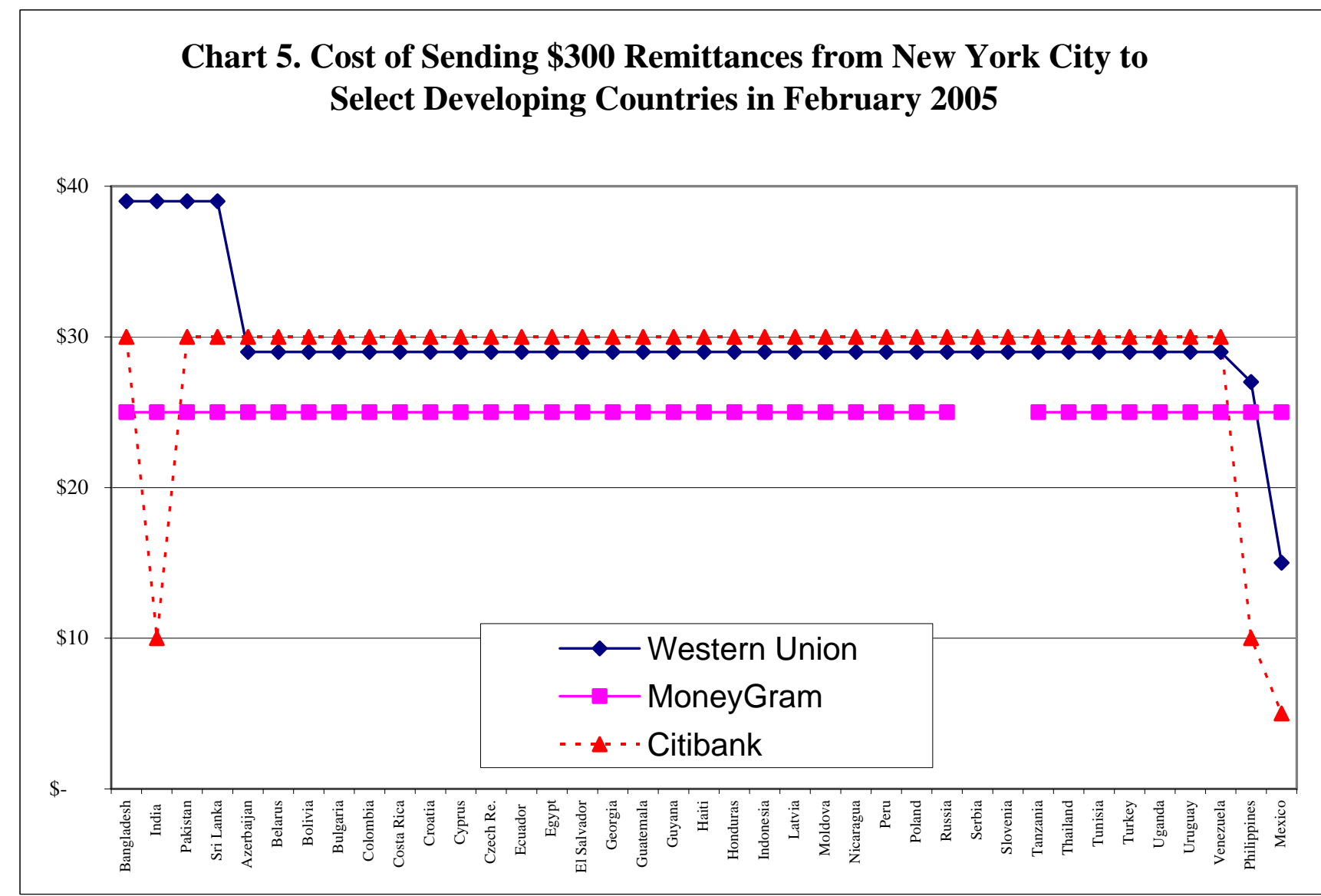

*It refers to the cost of sending \$300 dollars through Western Union, MoneyGram and Citibank in February 2005. Sources: Western Union’s web site (www.westernunion.com), MoneyGram’s website (www.moneygram.com) and Citibank’s website (web.dataus.citibank.com) 
Chart 5 above presents the average fee paid by senders in New York City to transfer $\$ 300$ dollars to the 40 developing countries covered in this survey by using the services of Western Union, MoneyGram -- the two largest worldwide money transfer firms - and Citibank, in February 2005.

It is beyond the scope of this survey to describe the different fees existing in each of the countries covered in this study. ${ }^{9}$ Fees vary not only from country to country, company to company, but also according to the instrument used to send the remittance (electronic wire, money order, etc), the amount sent, and the speed at which the funds become available to the beneficiary (15 minutes vs. several business days). ${ }^{10}$

Although the fees presented in chart 5 come from three companies - including two of the leading companies in remittances worldwide - for the purpose of this survey they can be seen as a good indicator to illustrate the range of fees existing for transferring remittances to developing countries. As shown in the chart, the cost of transferring \$300 dollars from New York City to most countries covered in the survey ranges between $\$ 25$ and $\$ 30$ dollars (or $8.3 \%$ and $10 \%$ of the sent amount, respectively). Remittances to Mexico and Philippines seem to be most competitive in this group of countries; a money transfer in the amount of $\$ 300$ dollars to Mexico costs between $\$ 5$ to $\$ 29$ dollars, and between $\$ 10$ to $\$ 27$ dollars to Philippines. ${ }^{11}$ On the other extreme, fees for remittances to Bangladesh, Pakistan and SriLanka range between $\$ 25$ and $\$ 39$ dollars (or $8.3 \%$ and 13\% of the amount sent). These costs do not include the exchange rate spread that may be applicable for transferring money to some jurisdictions (second component). In this type of service, beneficiaries do not pay any fee for receiving their funds (third component).

Clearly, the fees for sending remittances to most developing countries remain high. Although the fees may decline when the remittance amount increases, international studies on remittances and migration indicate that the average amount sent by most migrants to developing countries is in the range of $\$ 300$ dollars and that the money is sent on average every month. ${ }^{12}$

How can central banks in developing countries encourage a reduction of fees paid by senders and recipients of remittances? In principle, as explained in Figure 2, the scope for central banks in developing countries to foster the reduction of remittances fees is actually limited, because the fee that senders pay (component 1 ) is always determined by the financial institution located in the country where the transaction originates. The second fee component (exchange rate spreads) may sometimes be determined in the country where the transaction originates, in particular when the sender wants to know the exact amount the beneficiary will

\footnotetext{
${ }^{9}$ Manuel Orozco (2004b) provides the most comprehensive analysis of remittance fees charged by institutions based in the USA for money transfers to Latin American countries.

${ }^{10} \mathrm{R}$. Hernandez-Coss (2004) has documented the different costs of sending remittances from the USA to Mexico. His research shows that fees vary according to the city in which the transaction is originated and the town or city where the beneficiary in Mexico receives his money.

${ }^{11}$ On January 28, 2005, Bank of America announced the elimination of fees for money transfers between the USA and Mexico.

${ }^{12}$ See R. Hernandez-Coss (2004) and Manuel Orozco (2004) for Latin America.
} 
receive in local currency. Otherwise, component 2 will be determined by the local institution that pays the remittance to the beneficiary. As shown in Figure 2, only the third fee component, whenever applicable, is fully determined in the country where the beneficiary resides.

Given the multiple components of remittances fees, it is clear that efforts in developing (recipient) countries alone will not be sufficient to address the high remittance costs that senders and beneficiaries still pay. Efforts are needed in both sending and receiving countries in order to bring down remittance fees. A common approach and coordination between authorities of sending and recipient countries is needed to overcome factors that may hinder fees reduction, such as low competition among service providers, poor information disclosure for senders and recipients, poor payment system infrastructure that discourage migrants from using formal financial institutions to send money home, restrictions for cross-border operations, lack of trust of senders and recipients with financial institutions, etc.

At an international level, there has been a wide range of proposals that could help developing countries reduce remittance fees. Proposals include incentives for a more intensive use of electronic means to transfer money, such as electronic wires and dual debit cards, as opposed to money orders and drafts. Other proposals are to encourage migrants to do fewer but larger remittances transactions (as opposed to multiple transactions with small amounts), increase competition among firms by allowing more institutions to enter into the money transfer business, improve disclosure of remittances fees, etc. ${ }^{13}$

This survey examined three particular proposals that have been put forward recently in international fora: (i) improve information available to consumers in sending and recipient countries, (ii) allow non-bank financial institutions to have direct access to the central banks' clearing and settlement systems, and (iii) allow remittances recipients to have accounts in US dollars or any other international currency. ${ }^{14}$

\section{Improving Information Available to Consumers}

One of the questions that central banks were asked as part of this survey was which actions financial authorities had taken to ensure that senders and beneficiaries of remittances know the fees of each of the different products available in the marketplace to send money home. Interestingly, with the exception of Mexico and Sri Lanka, neither central banks nor government agencies offer consumers (senders and recipients of remittances) comparative information about the fees for using different products to send money home. With the exception of Mexico and Sri Lanka, consumers in all other countries covered in this survey are expected to inform themselves about the cost of using available instruments for sending money home. Also, financial and non-financial institutions are expected to inform their clients about all fees associated with their remittances transactions.

13 Some of these proposals are contained in the G8 Action Plan: "Applying the Power of Entrepreneurship to the Eradication of Poverty". This is a document issued at the G-8 Summit at Sea Island, Georgia on June 8-10, 2004. It is available at: http://www.g8usa.gov/d_060904a.htm.

${ }^{14}$ See, for instance, proposals formulated by USAID: http://www.dec.org/pdf_docs/PNADA184.pdf 
The examples of Mexico and Sri Lanka are important, because authorities in both countries have chosen to play an active role in collecting, comparing and disseminating the cost information of each of the available products for sending remittances from the USA (Mexico's main source of remittances) and Middle East Countries (Sri Lanka' main source of remittances), respectively.

Mexican authorities collect and compare the fees charged by banks and money transfer companies every month. Fees are disclosed in the internet by the Office of the Attorney for Consumer Affairs (http://www.profeco.gob.mx/html/envio/docinter.htm), as well as through consular offices. ${ }^{15}$ In Sri Lanka, the central bank plays also an important role in collecting and disseminating data on fees on remittance products offered by banks.

Because information is critical for competition in the marketplace, authorities, but also NGOs in other developing countries could consider playing an active role in collecting, comparing and disseminating information on a regular basis about the fees of different money transfer products. This may help migrants - in particular those that do not speak the language of their host country - to make better informed choices.

\section{Accounts in US Dollars or Other International Currency}

Another proposal to foster fee reductions is to allow residents in developing countries to have bank accounts in US dollars, or in any other major international currency. This would ensure that the amount in remittances that beneficiaries receive is the same amount sent by migrants. Moreover, it is argued that the beneficiary would have the option to convert the funds into local currency by choosing the institution that offers the best exchange rate.

Although this proposal seems reasonable, the survey found that in practice most developing countries already allow their citizens to open accounts in US dollars or any other major international currency. Of the 40 countries covered in the survey, 2 countries are dollarized Ecuador and El Salvador -- and 32 other countries already allow residents to open accounts in US dollars or any other major international currency. ${ }^{16}$ The only six developing countries in this survey that do not allow residents to have bank accounts in US dollars are: Bangladesh, Brazil, Colombia, Guyana, Tunisia, and Venezuela. In those countries, remittances must be paid in local currency to beneficiaries.

More studies are needed to assess the effectiveness of deposit accounts denominated in US dollars or any other major international currency for remittances beneficiaries. At this time, the most important challenge in developing countries is not the availability of dollardenominated bank accounts, but the fact that only a small amount of remittance beneficiaries

\footnotetext{
${ }^{15}$ PROFECO monitors the 22 largest money transfer companies and banks that provide remittance services from the USA to Mexico. Because fees also vary from city to city, PROFECO also monitors fees in 9 cities in the USA with the largest concentration of Mexican population.

${ }^{16}$ The use of dollar denominated accounts in developing countries should be examined further. In practice, some countries have in place several restrictions that make it impossible for most beneficiaries of remittances to open or maintain a bank account in US dollars.
} 
in developing countries actually have a bank account. As shown in the following chart, on average less than $40 \%$ of adults in developing countries have a savings or deposit account at a bank or micro-finance institution. As discussed below in Sector 4, the lack of a bank account prevents remittances beneficiaries in developing countries from using the remittances funds they receive regularly to access other financial products that may help them to improve their living conditions, such as consumer loans, mortgages, life and non-life insurance products, pension plans, etc.

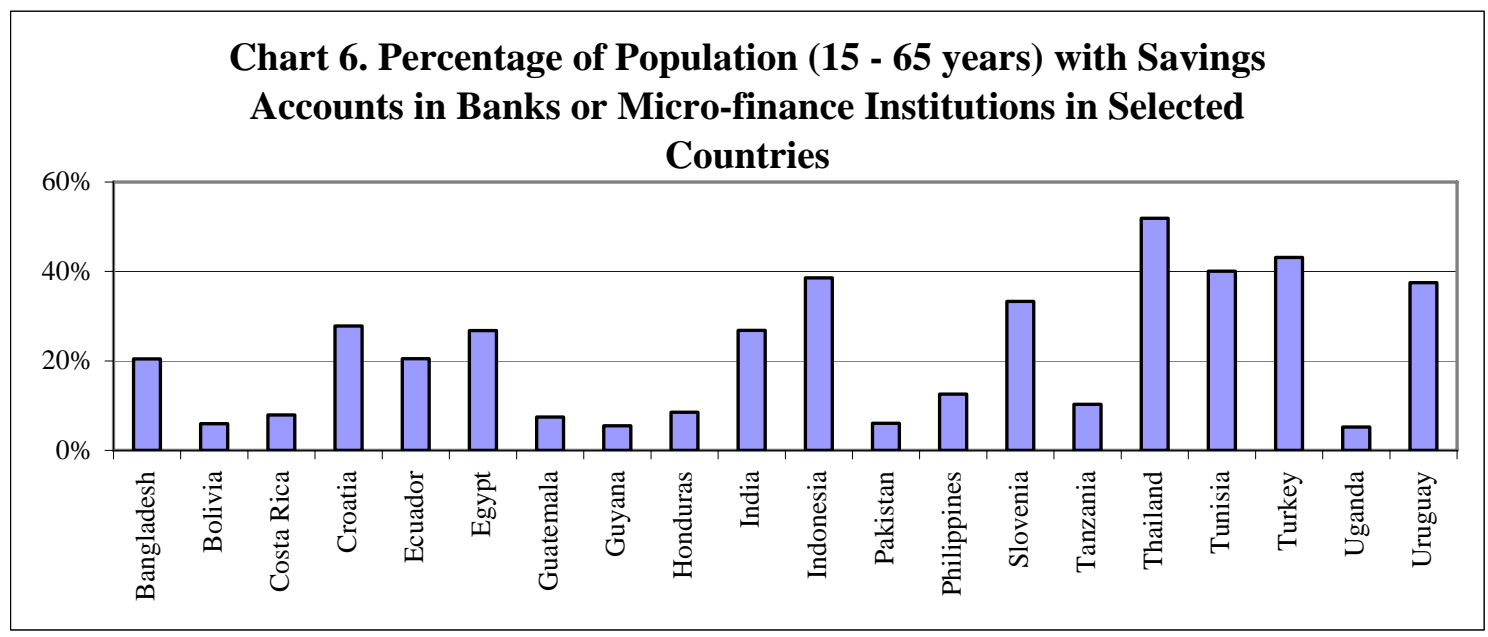

Source: With data from CGAP (2004) and World Bank’s World Development Indicators (2004).

\section{Access to Central Banks’ Clearing and Settlement Systems}

Another proposal to lower the cost of remittances has been to grant non-bank financial institutions direct access to the clearing and settlement systems that commercial banks use for their international operations - which in most cases are administered by central banks. This survey found that in practically all countries money transfer companies and other non-bank financial institutions - such as credit unions -- do not have direct access to the central banks' clearing and settlement systems. They must clear and settle their remittances transactions through commercial banks, which allegedly increases the cost they face in their remittances operations. By granting non-bank financial institutions direct access to clearing and settlement systems, it is believed that remittances fees would be reduced.

This survey found enormous skepticism among developing countries about the feasibility of this proposal. 35 out of 40 countries are not interested in pursuing this type of proposal, because they are concerned about the integrity of their clearing and settlement systems. Central banks think that most non-bank financial institutions in developing countries do not have the adequate technological infrastructure to directly participate in clearing and settlement systems. Furthermore, the volume of transactions that most of these institutions conduct is not large. Also, central banks believe that the reduction in remittances fees charged by non-bank financial institutions might not be significant just by granting them direct access to the central 
banks' clearing and settlement systems. According to this survey, only five countries -Azerbaijan, Belarus, Bolivia, Philippines, and Thailand - are contemplating the feasibility of granting access to clearing and settlement systems to a few large non-bank financial institutions (mostly to post offices).

At this time, no study is available comparing the average fees paid by non-bank financial institutions in developing countries to commercial banks that act as correspondent institutions.

Finally, one of the questions that central banks were asked as part of this survey was whether they had any legal powers to limit the fees that remittances beneficiaries pay to financial institutions when they collect their funds or limit the exchange rate spread institutions use to convert funds into local currency. In the European Union, for instance, the fees charged by financial institutions to their customers for money transfers between EU countries can not be higher than the fees charged for domestic money transfers. ${ }^{17}$

The survey found that few countries have legal powers to impose caps on the fees charged by financial institutions to customers receiving remittances. In this survey, only 9 of 40 countries -- Brazil, Bulgaria, Indonesia, Pakistan, Philippines, Russia, Thailand, Tunisia and Venezuela -- have legal powers to do this. However, with the exception of Pakistan and Venezuela, they have not used these prerogatives. Interestingly, all central banks indicated that even in the event that they had the legal powers to limit fees, they would not use them. Instead, central banks prefer that the fees be set by financial institutions themselves. Central banks themselves were in favor of more competition in the remittance industry, rather that direct intervention in it.

\footnotetext{
${ }^{17}$ Since July 1, 2003, the fees for cross-border bank transfers in euros within the European Union can not be higher than the cost of domestic transfers. Applicable regulation for cross-border transfers in the European Union is available at: http://europa.eu.int/comm/internal market/payments/index en. htm
} 


\section{Section 3: Regulatory Issues}

So far, little is known about the regulatory regime applicable to financial and non-financial institutions that receive and pay remittances in developing countries. The regulatory framework is important, because it determines - among other things -- who may participate in the remittances market, what sound practices participants need to observe for the delivery of remittances, what the reporting requirements are, and which standards of consumer protection need to be observed. This section presents the findings of the survey to three particular questions: Are all institutions delivering remittances in developing countries subject to oversight by the central bank or another financial authority? Which countries tax remittances and how? And finally, what are the usual channels to resolve consumer complaints on issues related to remittances in developing countries?

\section{Oversight of Institutions Delivering Remittances}

As described above, there is a wide range of institutions that pay remittances in developing countries, including, commercial banks, money transfer companies, post offices, exchange bureaus, credit unions, and other financial and non-financial institutions (micro-finance institutions, NGOs, travel agencies, etc). In most cases, banks, exchange bureaus and post offices in developing countries act as payment agents for banks or money transfer companies located in the countries where the remittances originate. As mentioned above, few institutions in developing countries have in practice simultaneous presence in both sending and recipient countries to be able to originate and deliver remittance transaction on a cross-border basis.

One of the issues this survey analyzed was whether the activities of the above institutions were subject to some form of oversight by the central bank or any other type of financial sector authority. The survey found that while banks, credit unions and exchange bureaus are subject to oversight by financial sector authorities, money transfer companies and post offices are often not. 
Chart 7. Are Money Transfer Companies Registered or Licensed by Financial Sector Authorities?

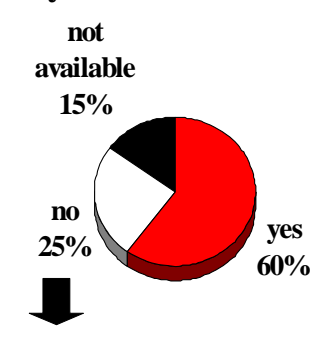

In those countries:

- Money transfer companies (MTCs) are not considered formal financial institutions.

- MTCs are licensed or registered by non-financial authorities.

As illustrated in Chart 7, in 60\% of developing countries covered in this survey financial sector authorities oversee the activities of money transfer companies. In $25 \%$ of countries, money transfer companies are not considered financial institutions and, as a result, they are not subject to registration or license requirements by financial sector authorities. In those countries, money transmitters are registered as commercial firms. As these companies grow through the expansion of branches and affiliated companies, the business of those affiliated companies is expected to be supervised by the money-transmitter itself, where a scheme of self-regulation operates.

It is beyond the scope of this paper to discuss the appropriate regulatory regime for money transfer companies. Whether they should remain unregulated or be subject to some degree of regulation and supervision by the authority is an issue that requires much more research. At this stage, it seems that from the point of view of anti-money laundering standards, there is a growing international consensus that money transfer companies should be subject to basic registration and data reporting requirements, as recently recommended by international bodies, such as the Financial Action Task Force (FATF). ${ }^{18}$

The data in this survey suggest that many developing countries are still in the process of reviewing/amending their legislation in order to implement this particular recommendation. One particular challenge for developing countries has been the need to issue regulations that

\footnotetext{
${ }^{18}$ In response to the terrorist attacks to the USA on September 11, 2001, the Financial Action Task Force (FATF) on money laundering issued eight special recommendations in October 2001 encouraging countries, among other things, to put in place a regulatory framework for licensing or registering money transfer providers (Special Recommendation number 6). The FATF membership is currently made up of thirty-one countries and territories, and two regional organizations. More information on FATF is available at: http://www1.oecd.org/fatf/
} 
strengthen the integrity of the domestic money transfer industry, but do not undermine the future development of this industry or put small firms in competitive disadvantage. ${ }^{19}$

\section{Resolution of Consumer Complaints}

An important area of regulation is related to the resolution of consumer complaints. The survey found that, for the countries where information is available -- such as Bolivia, Costa Rica, Ecuador, Georgia, India, Indonesia, Latvia, Mexico, Nicaragua, Pakistan, Philippines, Thailand and Tunisia -- the rate of consumer complaints in the local remittance industry is actually low, below $1 \%$ of the total number of transactions. Complaints normally refer to unexpected delays to receive funds due to misspelled names, or cases of fraud with money orders.

The survey found that the way in which countries deal with consumer complaints on issues related to remittances varies across developing countries. In most cases, consumer complaints tend to be resolved between financial institutions and their clients with no direct intervention of the authority. However, in 7 of the countries covered in the survey, financial authorities take an active approach if private parties cannot resolve their disputes. In three of the countries covered in the survey, there is an OMBUDSMAN established to resolve consumer issues, including India, Latvia and Mexico.

\section{Taxation of Remittances}

Another important issue covered in this survey relates to taxation of remittances in developing countries. In which countries are beneficiaries of remittances taxed? If so, how are they taxed?

\footnotetext{
${ }^{19}$ Reportedly, an increasing number of licensed money transfer firms in the state of New York in the United States are facing difficulties to operate, because commercial banks are shutting down their accounts in response to tight anti-money laundering regulations and fear of bad publicity. While tight regulations are needed to prevent money laundering activities, the closure of bank accounts to money transfer firms may severely affect remittance transfer industry. Money transfer companies need bank accounts to receive the remittance funds that their agents (grocery stores, gas stations, and other retail businesses) collect from customers.
} 


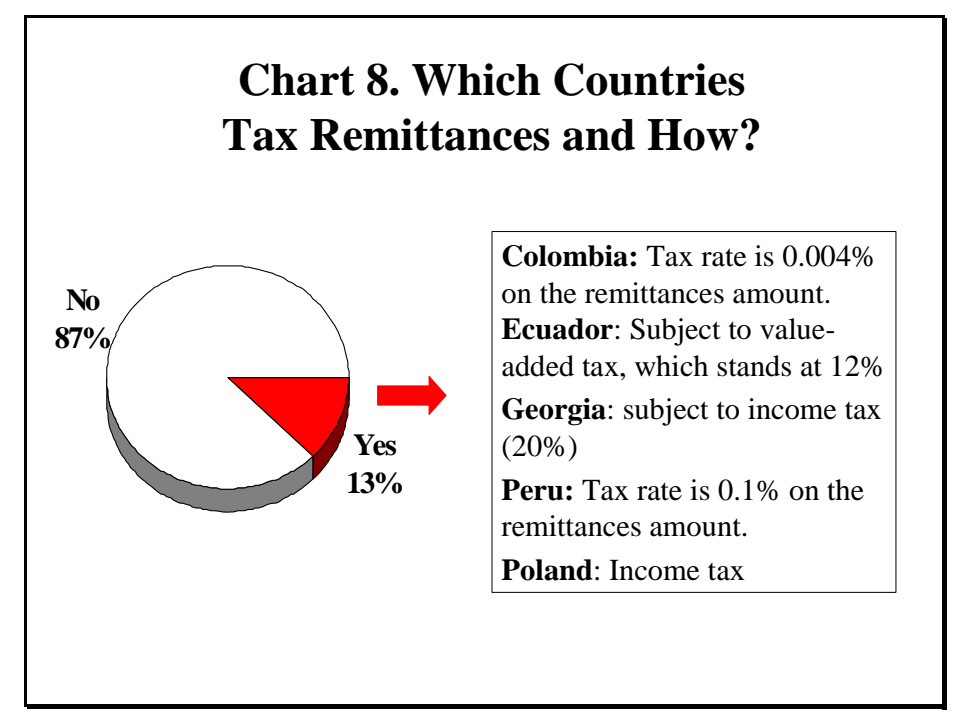

The survey found that only 5 of the 40 countries that participated in this survey tax remittances: Colombia, Ecuador, Georgia, Peru and Poland. The types of taxes applicable to remittances vary across countries in this group. In Colombia and Peru, for instance, remittances -- as well as all other types of financial transactions - are subject to a $0.004 \%$ and $0.1 \%$ tax rate, respectively. In Ecuador, remittances are subject only to value-added tax, which amounts to $12 \%$. In Georgia and Poland remittances are subject to income tax (exception is made on remittances coming from countries with which Poland has signed agreements to avoid double taxation). In Philippines, remittances are not taxed, but banks deduct withholding taxes only for interest income earned on remittances that have been deposited with banks.

At this time, more research is needed on the effect of taxes on remittances. In particular, it would be important to analyze how effective governments are in collecting taxes from remittance transactions and how large the revenues collected are. Moreover, it would be important to examine to what extent taxation encourages migrants to send money through informal channels instead of formal financial institutions and what effect taxation has on the overall development of the money transfer industry. 


\section{Section 4: Recent Initiatives in Developing Countries to Facilitate Remittance Flows through Formal Channels}

The last section of the survey examined two particular topics. First, are there any coordinated actions in sending and recipient countries to overcome the obstacles that hinder remittance flows between two countries? And secondly, what incentives have been put in place by developing countries to encourage remittances flows through formal channels?

\section{Bilateral Dialogue and Cooperation between Authorities}

As it has been discussed in this paper, some of the problems that deter the flow of remittances through formal channels between two countries cannot be resolved by financial authorities in recipient countries alone. Some problems (e.g. high cost of sending and transferring remittances, lack of incentives for migrants to send money through formal financial institutions, etc.) need to be addressed through active dialogue and cooperation between authorities in both sending and receiving countries.

The survey reviewed to what extent governments in developing countries had initiated a policy dialogue with their counterparts in sending countries in order to address the problems that hinder the flow of remittances through formal channels. As illustrated in Table 4, the survey found that five developing countries - Colombia, India, Mexico, Philippines and Turkey -- have an active dialogue with their main counterparts (in sending countries) to facilitate remittances flows.

Table 4. Policy Dialogue between Authorities in Sending and Recipient Countries

\begin{tabular}{|c|c|c|}
\hline $\begin{array}{l}\text { Sending } \\
\text { Country } \\
\end{array}$ & $\begin{array}{c}\text { Recipient } \\
\text { Country }\end{array}$ & Topics of Bilateral Policy Dialogue \\
\hline USA & Philippines & $\begin{array}{l}\text { - Memorandum of Understanding to reduce fees } \\
\text { - } \quad \text { Improve connectivity of payment systems }\end{array}$ \\
\hline USA & Mexico & $\begin{array}{l}\text { - Connectivity of payment systems } \\
\text { - Recognition of “matricula consular” }\end{array}$ \\
\hline USA & Colombia & - Access to bank services to migrants \\
\hline Germany & Turkey & - Taxation issues \\
\hline Canada & India & - Cooperation to reduce remittance fees \\
\hline
\end{tabular}

The central bank of Philippines and the US Federal Reserve, for instance, are currently discussing ways to improve the connectivity of their payment systems to facilitate electronic transfers between the two countries at a low cost. Moreover, the Ministry of Finance in Philippines and the US Treasury Department recently signed a Memorandum of Understanding to cooperate for the reduction of remittance fees between the two countries.

Similarly, the central banks of Mexico and the USA have signed an agreement that allows banks to transmit electronic fund transfers from the USA to Mexico through the Federal 
Reserve Banks' Automated Clearing House (ACH). The use of the ACH is expected to further reduce the cost of money transfers through banking institutions. Moreover, some legal obstacles that prevented Mexican undocumented workers to open bank accounts in the USA have recently been abolished. Now, non-legal Mexican aliens in the United States can open accounts in US-based commercial banks using identification cards issued by Mexican consulates. This has allowed Mexican aliens to send money home through banking institutions or other types of financial institutions and not just through money transfer companies or through the informal channels.

The fact that only five countries in this survey - Colombia, India, Mexico, Philippines, and Turkey -- have an active dialogue with their counterparts on issues related to remittances suggests that, despite the large amount of remittances developing countries receive every year, the topic of remittances still requires much more attention in most sending and recipient countries.

It is important that developing countries become aware of the volume and value of remittances inflows they receive and also become more active in addressing the problems that hinder remittances flows. Dialogue and cooperation between financial authorities in sending and recipient countries is needed to solve many of the problems hindering remittances flows. Not surprisingly, the corridors in which there is an active policy dialogue between sending and recipient countries are those with the lowest average remittance fees.

\section{Incentives for the Use of Formal Remittance Channels}

In principle, remittances can have an important multiplier effect in developing countries when they become savings in formal institutions and are accessible to other economic agents. At this time, however, there is no data to estimate what percentage of remittances that arrive through formal financial institutions become formal savings in the financial system. It is only known that a large part of households that receive remittances in developing countries do not have the option to save their money in formal financial institutions, because they do not have a deposit or savings account (see Chart 6 above). In those cases, money is either spent by remittance recipients or kept "under the mattress".

This survey examined what types of incentives authorities in developing countries have put in place to encourage migrants to send money back home through financial institutions. As illustrated in chart $9,35 \%$ of countries covered in this survey have put in place a variety of incentives to encourage migrants to use formal institutions to remit money home; they include tax breaks, higher interest rates for deposits and investments in local institutions, and possibility to purchase land at preferential prices. 


\section{Chart 9. Government Incentives to Transfer Remittances Through Formal Channels}

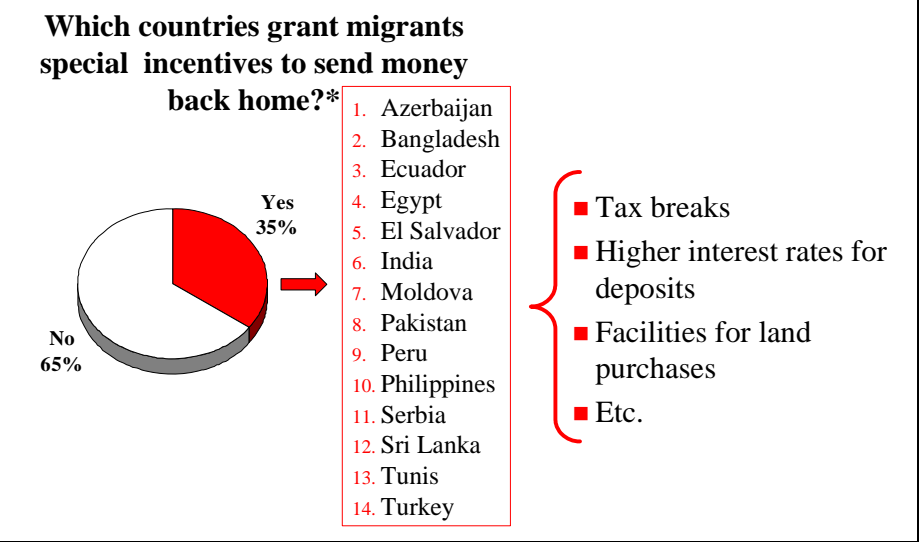

The establishment of a special category of deposit accounts at commercial banks where migrants can deposit their money earned abroad is one of the most common incentives used in developing countries to attract money transfers from abroad. These special deposit accounts give migrants preferential interest rates and the option to have accounts denominated in foreign currency. Bangladesh, India and Tunisia, for instance, have in place various financial products - such as deposit and savings accounts, money market accounts, etc. - specially designed to motivate migrants to transfer money to their local financial institutions, while they work abroad.

Tax breaks constitute another important instrument to encourage migrants to send money home through formal channels. Egypt, for instance, grants tax breaks up to ten years to migrants that send their money back through bank institutions. India and Sri Lanka offer migrants exemption of interest income from income tax. Finally, some countries -such as Egypt and Moldova-- offer migrants working abroad the opportunity to purchase land at preferential prices.

Mexico and El Salvador have established fund-matching schemes to finance small infrastructure projects in local communities. Under this type of schemes, for every dollar sent by Mexican and Salvadorian migrants to improve their communities in their home countries, the local or federal governments in those countries allocate $\$ 2$ or more to finance infrastructure projects, such as road pavement, dwelling, new bridges, etc.

At this time, more research is needed to determine the effectiveness of each those incentives in terms of promoting financial sector depth.

While government incentives may be an important tool to encourage migrants to send money through formal institutions, in some developing countries, privately-owned financial institutions are starting to offer migrants working abroad a wide range of financial services, including commercial loans and even mortgage products. Some financial institutions in Colombia, Mexico, Peru and Sri Lanka are offering migrants mortgage products to acquire 
real estate properties in their own country while they live and work abroad. Moreover, even some retail stores in El Salvador offer migrants the option to purchase goods that are delivered to their relatives in their home countries.

Clearly, much more can be done to maximize the developmental effect of remittances in developing countries by increasing the supply of financial services to both senders and recipients of remittances, which so far remain limited in most developing countries.

\section{Securitization of Future Remittance Flows}

Finally, an important issue covered in this survey is to what extent domestic banks in developing countries were making use of securitization of future remittance flows as a means to raise external financing and develop financial instruments around this type of transaction. From a financing perspective, workers' remittances constitute a future flow receivable - as credit card vouchers, oil or gas exports, telephone receivables, etc - that can be collateralized by financial institutions to raise additional capital. ${ }^{20}$ It is a way for banks in developing countries to borrow hard currencies by issuing bonds (collateralized by the future flow of remittances). Moreover, the proceeds of securitization provide banks additional resources to finance productive projects.

This survey found that only in four countries - Brazil, El Salvador, Mexico and Turkey - a few private financial institutions have securitized their future remittances flows. Banco do Brazil closed a \$300 million dollar securitization transaction in 2001, Banco Cuscatlán in El Salvador closed a \$125 million dollar transaction in 2003, Banamex of Mexico closed a \$200 million dollar transaction in 1999, and since 1999 several banks in Turkey have securitized a part of their remittance transactions. Given the large volume of remittance inflows to developing countries, which in 2003 amounted to \$96 billion dollars, securitization of remittance flows remains an unexploited source of additional financing for developing countries. More research is definitely needed to examine the factors that inhibit the securitization of remittance flows in developing countries and how to overcome them.

\footnotetext{
${ }^{20}$ See D. Ratha and Sushas Kethar (2004): Development Financing During a Crisis: Securitization of Future Receivables. Washington, DC, World Bank Working Paper Series No. 2582.
} 


\section{Conclusions}

Workers' remittances constitute an increasingly important source of income for many families in developing countries, especially poor families, whose relatives have emigrated to other countries in an effort to improve their own and their family's well-being. While in 1996 developing countries received \$58 billion dollars in remittances, in 2003 they received \$96 billion dollars. For 25 developing countries, remittances represented more than 5\% of their GDP in 2003. If the upward trend in international migration and mobility of people continues, workers' remittances are likely to become even more important for developing countries in the future.

Despite the increasing volume and value of remittance inflows to developing countries, this study found that most countries do not have in place the mechanisms that would allow them to maximize the developmental effect of remittance inflows. Data on remittances is not adequate, fees paid by senders and recipients of remittances are still high, and many recipients of remittances in developing countries do not have access to financial products that would allow them to improve their living conditions -such as bank accounts, life and non-life insurance products, consumer credit, etc. Moreover, if more people in developing countries had better options to save a part of their remittance income in formal financial institutions, then a larger part of the remittance flows that countries receive could be channeled to finance productive investments, thus fostering economic growth.

The study found that there is a need to improve the data on remittances in most countries covered in the survey. In many countries, remittance statistics are based on data that commercial banks provide to central banks or other financial sector authorities. However, remittances paid by money transfer companies - which tend to dominate the remittance industry in many countries - or other types of financial institutions (such as credit unions, post offices) are often not captured in remittance statistics in developing countries. Only 38\% of countries collect data from money transfer companies. Moreover, less than $25 \%$ of countries measure remittance transactions that occur through informal channels, such as money carried by migrants themselves to their home countries, money sent through "hawala" operators, and money sent through travel agencies or other informal means.

Given the limited coverage of existing remittance data, current statistics are most probably under-estimating the total value of remittances inflows to developing countries. It is important that developing countries improve their existing statistical tools to measure remittances inflows. Better data on remittances is important for the formulation of macroeconomic policy, because large remittance flows can affect the level of savings, investment and consumption. Furthermore, data on remittances constitutes an important tool to monitor cross-border flows of money and timely detect money-laundering or other illicit activities that may undermine the integrity of a financial system.

While there is a growing need in developing countries to improve remittance statistics, international guidance in this area is required. In particular, there is a need to establish simple and homogeneous reporting requirements across countries that do not undermine the competitive position of market players, especially small institutions. In addition, there is a 
need to develop better tools to measure remittance transactions that occur through increasingly sophisticated financial instruments, such as dual debit cards, store-value cards and other card-based transactions.

A second problem that requires attention of policy-makers in both sending and recipient countries is related to the high fees paid by senders and recipients of remittances. This survey found that senders usually pay up to $13 \%$ in fees for remittance transactions below \$300 dollars, which is the average amount migrants send every month to their home countries. Because fees are set by financial institutions in both source and destination countries, authorities in developing countries cannot foster the decline of fees alone. Cooperation between financial authorities in sending and recipient countries is required to address the high cost paid by consumers in their remittances transactions.

Not surprisingly, at this time the most competitive fees charged by financial institutions in the USA for remittances to developing countries are for money transfers to Mexico and Philippines, two developing countries that have had an active policy dialogue with their counterparts in the USA (the main source of their remittances) in recent years. Thanks to dialogue and cooperation between authorities, some of the obstacles that discouraged the use of formal channels to transfer money from the USA to Mexico -- such as the lack of bank accounts for non-documented Mexican workers in the USA - have been eliminated. Moreover, authorities in the Philippines and USA have recently signed a Memorandum of Understanding for cooperation on remittance issues and are currently discussing steps for the future connectivity of their payment systems. Mexico and USA have recently put in operation a mechanism that allows rapid electronic transfers between banks in both countries and at low cost through the FED’s Automated Clearing House.

Although dialogue and cooperation between sending and recipient countries is needed to remove the obstacles that hinder remittance flows between countries, only five countries in this survey - Colombia, India, Mexico, Philippines, and Turkey -- have an active dialogue with their counterparts on issues related to remittances. This suggests that, despite the large amount of remittances developing countries receive every year, the topic of remittances has not yet become an important public policy issue in the bilateral agenda between governments in sending and recipient countries.

Recently, a series of proposals to foster a reduction in fees has been formulated in international fora. Proposals include establishment of foreign currency-denominated accounts in banks in developing countries, better dissemination of remittance costs in sending and recipient countries, and authorization to non-bank financial institutions to directly participate in the clearing and settlement systems that commercial banks use for their cross-border operations.

Some of these proposals seem to be already implemented in some developing countries. For instance, the survey found that in practice most developing countries already allow their citizens to open accounts in US dollars or any other major international currency. Unfortunately, on average only 35\% of adults in developing countries have a bank account. 
There are proposals for reducing remittance fees worth considering. For instance, the survey found that authorities in Mexico and Sri Lanka play an active role in informing senders and recipients of remittances on a regular basis about the cost of using different instruments for sending and receiving money from abroad. Because information is critical for competition in the marketplace, authorities or NGOs in other developing countries could consider playing an active role in collecting, comparing and disseminating information about fees associated with different money transfer products.

Another proposal to lower the cost of remittances has been to authorize non-bank financial institutions (money transfer companies and other firms) direct access to the clearing and settlement systems that commercial banks use for their international operations. In most countries, non-bank financial institutions do not have direct access to the central banks' clearing and settlement systems. They clear and settle their remittances transactions through commercial banks. This survey found, however, enormous skepticism about this proposal, because central banks think that most non-bank financial institutions in developing countries do not have the adequate technological infrastructure to directly participate in clearing and settlement systems. Moreover, central banks believe the risk of allowing non-bank financial institutions direct access to the central banks' clearing and settlement systems could be large, while the reduction in remittances fees charged by these institutions might not be significant.

Another problem faced in developing countries is related to the oversight of institutions involved in remittances transactions. This survey found that in $25 \%$ of countries financial sector authorities do not oversee money transfer companies -- which conduct a large share of remittances transactions. Because in most developing countries this type of company is not considered to be a formal financial institution, they are not subject to registration or licensing by financial sector authorities. As a result, no reporting requirements exist. Given the increasing international concerns on money laundering and terrorism financing issues, it is important that basic registration and reporting requirements are introduced in developing countries for this type of company. Registration and reporting requirements should be designed in a way that does not deter the further development of this type of financial institution.

Finally, from a developmental point of view, one of the major challenges for policy makers in developing countries is to motivate senders and recipients of remittances to conduct their money transfer operations through formal financial institutions. In that way, remittances could become formal savings and deposits in financial institutions and, thus have a multiplier effect in developing countries. This survey found that on average less than $35 \%$ of adults in developing countries have a deposit or savings account in financial institutions. This suggest that a large part of remittances are paid in cash and used for consumption purposes or kept "under the mattress".

According to this survey, less than $35 \%$ of countries have incentives in place to encourage senders of remittances to transfer their funds through formal financial institutions. It is interesting to note that a growing number of private financial institutions in developing countries are starting to offer migrants working abroad a wide range of financial services, including commercial loans and even mortgage products. Some financial institutions in 
Colombia, Mexico, Peru and Sri Lanka are offering migrants mortgage products to acquire real estate properties in their own country while they live and work abroad. Moreover, even some retail stores in El Salvador offer migrants the option to purchase goods that are delivered to their relatives in their home countries.

Clearly, much more can be done to maximize the developmental effect of remittances in developing countries by increasing the supply of financial services to both senders and recipients of remittances. Products that could be offered to poor families receiving remittances include deposit and savings accounts, consumer loans, mortgages, life and non-life insurance products, pensions, etc. This would not only deepen the financial system, but more importantly help recipients of remittances improve their living conditions.

Financial institutions in developing countries can also take advantage of the large volumes of remittances inflows countries receive by securitizing remittance flows and, thus, increase the availability of funds for productive investments. This survey found that the use of remittance securitizations in developing countries remains limited. In the countries covered in this survey, only four securitizations of remittances have taken place in recent years for a total amount below $\$ 1$ billion dollars. Given the value of remittance inflows to developing countries, which in 2003 amounted to $\$ 96$ billion dollars, securitization of remittance flows remains an unexploited source of additional financing for developing countries.

Clearly, simultaneous efforts on various fronts are needed to improve the development impact of remittances in developing countries. As the paper has described, there is a need to improve data on remittances, establish a competitive environment that leads to further decline in remittance fees, improve regulation of money transfer companies, broaden access of population to financial services by developing new products for households receiving remittances on a regular basis, etc. To address all these challenges, countries could consider the convenience of establishing a national policy on remittances, instead of dealing with them on a piecemeal basis. A national policy on remittances could provide the framework under which the efforts of financial sector authorities, migration authorities, poverty alleviation agencies, and ministries of foreign affairs, among others, could be aggregated and coordinated towards the achievement of common goals. Moreover, a national policy on remittances could help place the topic of remittances on the national development agenda, especially in countries where remittances already represent a large percentage of their GDP. 


\section{REFERENCES}

APEC. June 3-4, 2004. Symposium on "Alternative Remittances Systems: Shaping the Remittances Market by Shifting to Formal Systems,” June 3-4, 2004. www1.worldbank.org/finance/html/amlcft/Tokyo\%20ARS\%20symposium.htm.

Consultative Group to Assist the Poor (CGAP). 2004. Financial Institutions with a Double Bottom Line: Implications for the Future of Microfinance. Washington, DC, Ocassional Paper No. 8.

Federal Reserve Bank of Atlanta. 2004. Conference on "Payments in the Americas". Atlanta, GA. October 7-8, 2004. http://www.frbatlanta.org/news/news_newsrouter.cfm? news_type=CONFERENCES.

Hernández-Coss, Raúl. 2004. "Lessons from the U.S.-Mexico Remittances Corridor on Shifting from Informal to Formal Transfer Systems.” World Bank, Washington, DC. http://www1.worldbank.org/finance/html/amlcft/docs/Rem_CS/USMex_CS_Eng.pdf.

—. Forthcoming. "Lessons from the Canada - Vietnam Remittances Corridor on Shifting from Informal to Formal Transfer Systems.” World Bank, Washington, DC.

International Monetary Fund. Balance of Payments Yearbook. Washington, D.C. Various Issues.

Maimbo, S., Adams, R., Agrawal, R. and Passas, N. 2005. "Migrant Labor Remittances in South Asia. Directions in Development.” Washington D.C: World Bank, Processed.

Multilateral Investment Fund. 2002. "Sending Money Home: Remittances to Latin America and the Caribbean." Inter-American Development Bank. http://www.iadb.org /mif/v2/files/StudyPE2004eng.pdf.

OECD. 2004. Working Abroad. The Benefits Flowing from Nationals Working in other Economies. Paris, OECD.

Orozco, Manuel. 2004a. "Mexican Hometown Associations and Development Opportunities”. Journal of International Affairs, Vol. 57, No. 2.

Orozco, Manuel. 2004b. "The Remittance Marketplace: Prices, Policy and Financial Institutions”. Washington, DC, Pre-Hispanic Center.

Patterson, Neil and Jens Reincke. 2005. "Remittances in the Balance of Payments Framework". IMF, Washington, DC. Paper presented at the International Technical Meeting on Measuring Migrant Remittances, January 24-25, 2005. It is available at: www.worldbank.org/data/remittances.htm. 
Ratha, Dilip. 2003. "Workers' Remittances-An Important and Stable Source of External Development Finance.” In Global Development Finance 2003 (chapter 7). Washington, D.C., World Bank.

Ratha, Dilip and Sushas Kethar. 2004. Development Financing During a Crisis: Securitization of Future Receivables. Washington, DC, World Bank Working Paper Series No 2582.

United Nations. 2004. World Economic and Social Survey 2004. International Migration. New York, United Nations.

World Bank. 2005. World Development Report. Washington, DC.

World Council of Credit Unions. 2004. "A Technical Guide to Remittances: The Credit Union Experience.” www.woccu.org/development/guide/remittances_techguide. pdf.

World Savings Banks Institute. 2004. Conference on "Access to Finance”. Brussels, 28-29 October, 2004. http://www.savings-banksevents.org/atf/programme.htm 


\section{Annex 1. World Bank Survey on Remittances- Questions for Central Banks}

$1 \quad$ Basic Data on Remittance Inflows

1.1 Please indicate what the source(s) of your official data on remittances are?

a. Reports from firms specialized in money transfers (Western Union, Money Gram, etc.)

b. Reports from banking institutions

c. Reports from exchange bureaus

d. Reports from other financial institutions that deliver remittances (e.g. micro-finance institutions, credit unions, saving and loans companies, etc)

e. Reports from non-financial institutions that deliver remittances (e.g. post offices)

f. Reports from settlement and clearance agencies

g. Information reported by migrants themselves entering the country (at airports or other points of entry)

h. Other, please specify

1.2 What type of transactions do you record as remittances?

a. Electronic transfers

b. Drafts

c. Money orders

d. Withdrawals at automated teller machines (ATMs) using cards issued by foreign financial institutions

e. Money reported by migrants visiting their home country at point of entry

f. Use of pre-paid cards for remittances

g. Checks issued by banks in foreign jurisdictions

h. Other (please specify)

1.3 Does the data you collect allow you to identity the source country of remittances?

1.4 Does the data you collect allow you to identify the number of remittances transactions?

1.5 Do you disclose information on remittances to the public?

1.6 If so, how often is the information disclosed?

a. Every month

b. Every quarter

c. Every year

d. Other

1.7 Which year did you start to collect information on remittances?

1.8 Are there other government agencies collecting information on remittances in your country? If so, which?

1.9 Do you have any plans to improve the coverage of your data and the methodology used to measure the volume and structure of remittances? If so, please describe your current or future initiatives on this matter. 
2 Basic Data on Remittance Outflows (money sent by foreign workers living in your country)

2.1 Please indicate what the source(s) of your official data on remittances outflows are?

a. Reports from firms specialized in money transfers (Western Union, Money Gram, etc.)

b. Reports from banking institutions

c. Reports from exchange bureaus

d. Other, please specify

2.2 What type of transactions do you record as remittances outflows?

a. Electronic transfers

b. Drafts

c. Money orders

d. Other (please specify)

2.3 Does the data you collect allow you to identity the destination country of remittances? 2.4 Does the data you collect allow you to identify the number of remittances transactions?

\section{Statistics on Remittances (Inflows)}

3.1 How many nationals of your country live overseas (number of migrants and migrants as a percentage of total population)?

3.2 Do you know what has been the outflow of migrants in each of the past five years?

3.3 Do you know in which countries do migrants live (top five destination countries)?

3.4 Do you have specific information regarding the number of migrants of your country living in each foreign country (top 5 destination countries)?

3.5 Do you have any statistics on the average amount of remittances sent by migrants every month and every year?

3.6 Do you know how often migrants actually send remittances (on average) to their families and relatives?

a. Every month

b. Every two months

c. Every three months

d. Every six months

e. Once a year

3.7 Could you please provide the following data on remittances for the past three years? 
Table 1.

\begin{tabular}{|l|l|l|l|l|l|l|}
\hline \multirow{2}{*}{$\begin{array}{c}\text { Instrument to } \\
\begin{array}{c}\text { transfer } \\
\text { remittances }\end{array}\end{array}$} & $\begin{array}{c}\text { Number of } \\
\text { transactions }\end{array}$ & $\begin{array}{c}\text { Volume of } \\
\text { transactions } \\
\text { (\$) }\end{array}$ & $\begin{array}{c}\text { Number of } \\
\text { transactions }\end{array}$ & $\begin{array}{c}\text { Volume of } \\
\text { transactions } \\
\text { (\$) }\end{array}$ & $\begin{array}{c}\text { Number of } \\
\text { transactions }\end{array}$ & $\begin{array}{c}\text { Volume of } \\
\text { transactions } \\
\text { (\$) }\end{array}$ \\
\hline electronic wires & & & & & & \\
\hline drafts & & & & & & \\
\hline debit cards & & & & & & \\
\hline money orders & & & & & & \\
\hline Pre-paid cards & & & & & & \\
\hline checks & & & & & \\
\hline $\begin{array}{l}\text { money sent through } \\
\text { relatives traveling to } \\
\text { home country }\end{array}$ & & & & & & \\
\hline $\begin{array}{l}\text { Other, please } \\
\text { specify }\end{array}$ & & & & & & \\
\hline \multicolumn{1}{|c|}{ Total } & & & & & & \\
\hline
\end{tabular}

3.8 Which country (countries) is the major source of your remittances?

3.9 Please indicate which types of institutions of table 2 deliver remittances in your country.

Table 2.

\begin{tabular}{|l|l|l|l|}
\hline $\begin{array}{c}\text { Types of financial and non-financial institutions } \\
\text { delivering remittances in your country }\end{array}$ & $\begin{array}{l}\text { Number of } \\
\text { institutions }\end{array}$ & $\begin{array}{c}\text { Who supervises } \\
\text { these } \\
\text { institutions? }\end{array}$ & $\begin{array}{c}\text { Share of the } \\
\text { market of } \\
\text { remittances (\%) }\end{array}$ \\
\hline $\begin{array}{l}\text { Firms specialized in money transfers (Western } \\
\text { Union, Money Gram, etc.) }\end{array}$ & & & \\
\hline Private banking institutions & & & \\
\hline State-owned banks & & & \\
\hline Exchange bureaus & & \\
\hline $\begin{array}{l}\text { Other financial institutions (e.g. micro-finance } \\
\text { institutions, credit unions, saving and loans } \\
\text { companies, etc) }\end{array}$ & & \\
\hline $\begin{array}{l}\text { Non-financial institutions (e.g. post offices, } \\
\text { commercial retail chains, travel agencies, etc.) }\end{array}$ & & & \\
\hline Other & & & \\
\hline
\end{tabular}

$4 \quad$ Financial infrastructure supporting remittances - payment systems, technology, players 4.1 Which institutions delivering remittances in your country have access to the central bank's clearing and settlement systems (commercial banks, exchange bureaus, micro-finance institutions, credit unions, etc.)

4.2 If there are institutions that deliver remittances in your country which do not have access to the central bank's clearing and settlement system, what is the reason for that?

4.3 Are there any plans to increase the access of institutions delivering remittances to the central bank's clearing and settlement systems? If so, please describe your plans.

4.4 For institutions with no access to the central bank's clearing and settlement systems, what clearing and settlement systems do they use? 
4.5 Can financial institutions operating in your country make use of the US Automated Clearing House system to receive remittances?

4.6 If so, which institutions have access to the US Automated Clearing House (banks, exchange bureaus, micro-finance institutions, credit unions, etc.)?

4.7 How do banks deliver funds in locations where they do not have branches?

5 Best practices in the market, good practices and bad practices used by market players

5.1 From your perspective, what are the areas that require more attention by authorities in order to make the transfer and delivery of remittances more efficient and secure? Please select all applicable areas.

a. Better statistics on remittances (amount, characteristics, composition)

b. Better statistics and studies on migrants (location, social background)

c. Competition among institutions transferring and delivering remittances

d. Delivery of remittances in rural areas

e. New technologies and products for the transfer and delivery of remittances

f. Financial integrity issues

g. Other, please specify

5.2 From your perspective, are there any practices that should be prohibited in order to make the transfer and delivery of remittances more secure?

5.3 Have you experienced cases of fraud or other types of losses in the transfer and delivery of remittances?

5.4 Is there any office in your country responsible for handling and resolving customer complaints on issues related to transfer and delivery of remittances?

5.5 If so, what is the office?

5.6 If not, how are issues related to consumer complaints on remittances normally resolved?

$6 \quad$ Regulatory environment

6.1 According to your laws, which institutions can receive and deliver remittances from foreign sources?

a. Private commercial banks

b. Public-owned financial institutions

c. Post offices

d. Exchange bureaus,

e. Credit unions

f. Micro-finance institutions

g. Other

6.2 Do the above institutions need to be registered in order to receive and deliver remittances?

6.3 How many institutions delivering remittances have been officially registered so far?

6.4 Who supervises each of the above institutions?

6.5 In the particular case of money transfer companies, what are the capital requirements for establishing this type of firms and who grants the licensing?

6.6 Are remittances taxed? If so, what type of taxes apply to remittances and what is the tax rate $(\mathrm{s})$ ? 
6.7 How are consumers informed about the cost of sending remittances in the source and destination country?

a. Each financial institution informs the public about its fees

b. A non-government organization (NGO) provides comparative data to the public on the costs of sending remittances

c. A government entity regularly provides comparative data to the public on the costs of sending remittances

6.8 Does your country allow the general public to have deposit accounts in US dollars?

6.9 How is the exchange rate for retail transactions in your country determined (conversion of remittances to local currency), by market or by government?

6.10 Do you have any legal powers to issue regulation to limit the fees related to the transfer and delivery of remittances (such as exchange rate to be used for the transaction, currency in which the delivery of remittances occurs, fees for ATM withdrawals, etc.)?

6.11 Have you used these legal powers in order to lower the cost of remittances in the past three years?

$7 \quad$ Public Policy Issues

7.1 What is, in your opinion, inhibiting migrants from using formal channels to transfer remittances to your country?

a. Lack of valid identification in home country

b. Lack of access to financial institutions in home country

c. Mistrust or lack of information about electronic transfers

d. High costs of services

e. Other

7.2 In your opinion, what needs to be done in your own country to encourage migrants to transfer their remittances through formal channels?

a. Lift foreign exchange restrictions

b. Allow remittances to be delivered in US dollars or Euros or any other international currency and not just in local currency.

c. Improve postal service infrastructure to be able to deliver remittances to more locations

d. Other, please specify

7.3 What incentives do you grant migrants to transfer their money back to the country (such as attractive investment options, purchases of land, tax breaks, etc.)? Please describe them.

7.4 What efforts have financial authorities recently undertaken to expand the outreach of remittances services to rural areas and remote locations in your country in which population have no means to receive their remittances?

7.5 In your opinion, what else could be done in your country to improve the transfer and delivery of remittances to rural areas and remote locations?

7.6 Do financial authorities in your country have any plans to foster the use of formal mechanisms to transfer remittances (banks and other registered financial institutions), instead of informal channels (money sent by migrants through relatives traveling to home country)? If so, please describe the plans. If actions are already underway, please describe them.

7.7 Do you have any plans to make use of the amount of funds your country receive in remittances each year to obtain additional financing in the local or international markets (e.g. 
securitizing future flows of remittances)? If so, please describe the plans. If actions are already underway, please describe them.

7.8 What type of actions has your government conducted in coordination with counterparts in foreign countries (source of remittances) in order to facilitate and lower the cost of the transfer of remittances? Please describe them, if any.

7.9 At an international level, what can the World Bank do to facilitate the rapid, secure and inexpensive transfer of remittances of migrants to their home countries?

Name of person(s) that responded the questionnaire:

Position:

Contact information: 


\section{Annex 2 - Country Data}

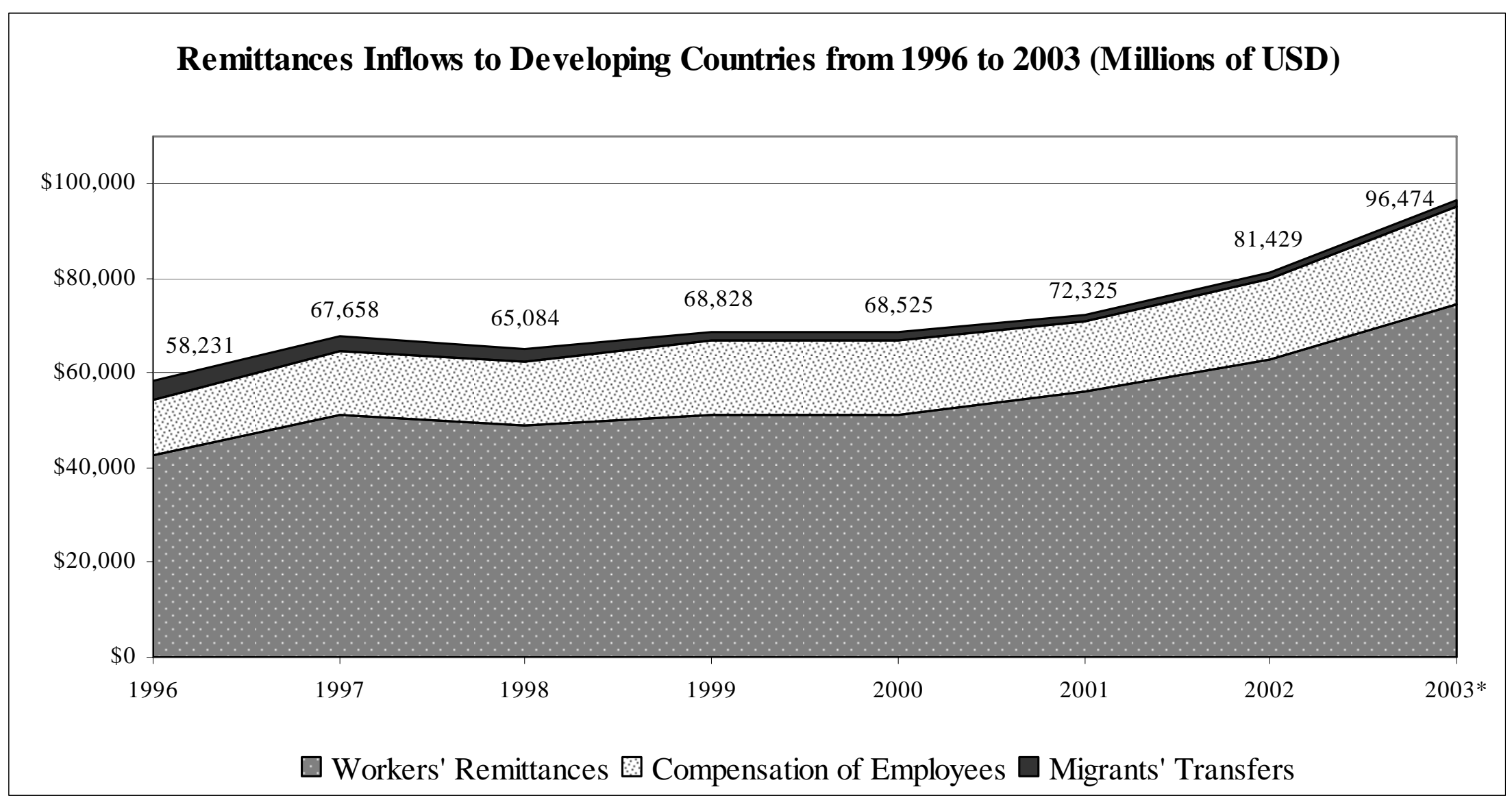

Source: International Monetary Fund. Balance of Payments Yearbook. Washington, D.C. 2004. 


\section{Annex 3. Recent Country Initiatives to Improve Statistical Data on Remittances}

Azerbaijan: Improve reporting system in light of actions to fight against money laundering and financing of terrorism.

Belarus: Develop new tools to measure remittances sent through relatives and in letters.

Bolivia: Increase statistical coverage of institutions paying remittances.

Bulgaria: Collect data from banks on a transaction by transaction basis.

Colombia: Measure remittances that are paid through ATM's.

Costa Rica: Increase the number of financial institutions covered in sample surveys.

Ecuador: Introduce a regional survey of households with the support of religious organizations and universities.

El Salvador: Introduce system of electronic reporting of remittance payments by commercial banks.

Guyana: Include remittances via post offices and persons traveling to home country.

Honduras: Apply a survey to migrants visiting home country every six months.

India: Establish new system to capture foreign exchange transactions, including remittances.

Indonesia: Improve the methodology used to identify workers' remittance transactions through banks.

Moldova: Conduct a household survey on remittances in September-October 2004.

Nicaragua: Increase the base of survey interviews and coverage of the statistical data.

Peru: Increase number of institutions that should report data to financial authorities.

Philippines: Currently, data on remittances are based on transactions that pass through the banking system. There is an on-going initiative to expand the coverage of the estimates of OFW remittances beyond the bank reports through the application of parameters derived from the results of the SOF.

Poland: Proposals to make a better distinction between compensation of employees and workers remittances in the Balance of Payment Statistics. Also, central bank is analyzing the convenience of using data from the German Balance of Payments as a supplementary data source.

Russia: Revise data report form for banking institutions.

Serbia and Montenegro: Improve data coverage.

Slovenia: With abolishing the role of ITRS in balance of payments and changing to direct reporting (due to EU regulation no. 2650), the quality of data on remittances will deteriorate, central bank is analyzing ways to improve data.

Sri-Lanka: Survey is being developed to better measure formal and informal money transfers.

Thailand: Improve payment systems data in 2005, which will cover major payment systems. Uganda: Use of national household surveys.

Venezuela: Improving system that measures foreign exchange transactions. 